\title{
Purification of polyclonal Immunoglobulin G from human serum using LigaGuardTM and LigaTrapTM adsorbents
}

\author{
Wenning $\mathrm{Chu}^{1}$, Hannah Reese ${ }^{1}$, Dipendra Bhandari ${ }^{2}$, Jae $\mathrm{Sly}^{2}$, Michael Crapanzano ${ }^{2}$, and \\ Stefano Menegatti ${ }^{1}$ \\ ${ }^{1}$ North Carolina State University \\ ${ }^{2}$ LigaTrap Technologies LLC
}

July 11, 2021

\begin{abstract}
This study presents the chromatographic purification of immunoglobulin G (IgG) from human plasma using a two-column process integrating the peptide-based adsorbents LigaGuardTM, which captures non-Ig plasma proteins in flow-through mode, and LigaTrapTM, which isolates IgG in bind-and-elute. Buffer composition and column loading were optimized for both adsorbents. Two process configurations were evaluated. In the first design, plasma was fed to a LigaGuardTM column to capture plasma proteins, the effluent was loaded on the LigaTrapTM column, and the bound IgG was eluted with $63.8 \%$ global recovery and $99.7 \%$ purity; in comparison, Protein G agarose afforded $\sim 67 \%$ recovery and $97.2 \%$ purity. In the alternative design, the LigaGuardTM column was utilized to polish the LigaTrapTM elution stream, affording $82.3 \%$ global recovery and $98.8 \%$ purity. Collectively, these results demonstrate the potential of a fully chromatographic process for purifying polyclonal IgG from plasma feedstocks.
\end{abstract}

Purification of polyclonal Immunoglobulin G from human serum using LigaGuard ${ }^{\text {TM }}$ and LigaTrap $^{\mathrm{TM}}$ adsorbents

Wenning $\mathrm{Chu}^{1}$, Hannah R. Reese ${ }^{1}$, Dipendra Bhandari ${ }^{2}$, Jae $\mathrm{Sly}^{2}$, Michael Crapanzano ${ }^{2}$, and Stefano Menegatti ${ }^{1,2,3,{ }^{*}}$

${ }^{1}$ Department of Chemical and Biomolecular Engineering, North Carolina State University, 911 Partners Way, Raleigh, NC 27606

${ }^{2}$ LigaTrap Technologies LLC, Durham, NC 27701

${ }^{4}$ Biomanufacturing Training and Education Center (BTEC), North Carolina State University, 850 Oval Dr, Raleigh, NC 27606

* corresponding author: smenega@ncsu.edu; (919) 5156398.

Abstract. This study presents the chromatographic purification of immunoglobulin G (IgG) from human plasma using a two-column process integrating the peptide-based adsorbents LigaGuard ${ }^{\mathrm{TM}}$, which captures non-Ig plasma proteins in flow-through mode, and LigaTrap ${ }^{\mathrm{TM}}$, which isolates IgG in bind-and-elute. Buffer composition and column loading were optimized for both adsorbents. Two process configurations were evaluated. In the first design, plasma was fed to a LigaGuard ${ }^{\mathrm{TM}}$ column to capture plasma proteins, the effluent was loaded on the LigaTrap ${ }^{\mathrm{TM}}$ column, and the bound IgG was eluted with $63.8 \%$ global recovery and $99.7 \%$ purity; in comparison, Protein G agarose afforded $\sim 67 \%$ recovery and $97.2 \%$ purity. In the alternative design, the LigaGuard ${ }^{\mathrm{TM}}$ column was utilized to polish the LigaTrap ${ }^{\mathrm{TM}}$ elution stream, 
affording $82.3 \%$ global recovery and $98.8 \%$ purity. Collectively, these results demonstrate the potential of a fully chromatographic process for purifying polyclonal IgG from plasma feedstocks.

Keywords: Affinity ligands, protein chromatography, LigaGuard ${ }^{\mathrm{TM}}$, LigaTrap ${ }^{\mathrm{TM}}$, polyclonal antibodies.

\section{Introduction}

Polyclonal immunoglobulin G (pIgG), also known as Intravenous immunoglobulins (IVIgs), is a therapeutic preparation containing polyspecific IgGs extracted from the pooled plasma of healthy donors $\left[{ }^{1}\right]$. Since $1980 \mathrm{~s}$, IVIg has been extensively investigated in term of molecular structure and functions, purification strategy, and clinical applications $\left[{ }^{1}\right]$. A key component of IVIg formulations are antibodies targeting microbial antigens, which, together with autoantibodies and anti-idiotypic antibodies $\left[{ }^{2,3}\right]$, provide the biomolecular arsenal forming the immune defense $\left[{ }^{4-6}\right]$. Accordingly, IVIg has been widely utilized in treating immunodeficiency as well as autoimmune and inflammatory disorders $\left[{ }^{7,8}\right]$. Furthermore, IVIgs from immunized donors have also shown to aid patients stricken by infectious diseases $\left[{ }^{9,10}\right]$; in this context, the most recent case includes clinical evidence of pooled plasma from SARS-CoV-2 convalescent donors successfully utilized to treat patients affected by severe acute respiratory syndrome (SARS COVID19) [11-13 $]$.

With a steadily increasing annual consumption [14 ], large-scale IVIg production poses a mounting pressure on companies operating in the plasma product landscape. Currently, pIgG extraction from pooled plasma is based on the Cohn-Oncley or the Kistler-Nitschmann processes, which fractionate plasma proteins by precipitation under controlled conditions including ethanol and caprylate concentration, conductivity, temperature, and $\mathrm{pH}\left[{ }^{15-17}\right]$. The immunoglobulin-rich fractions undergo subsequent processing via ion exchange chromatography to isolate pIgG $\left[{ }^{18,19,20}\right]$. These processes, however, are inherently batch operations, characterized by high capital and operational costs and long processing times. Furthermore, Protein $\mathrm{A} / \mathrm{G}$ affinity chromatography employed in the purification of therapeutic monoclonal antibodies ( $\mathrm{mAb}$ ) is unsuitable for downstream processing of IVIgs: the enormous volumes of plasma to be processed are in fact incompatible with the high cost of Protein A/G-based resins, and the related risks of antibody aggregation and ligand leakage during elution [21,22].

Fully chromatographic fractionation of plasma has the potential to substantially accelerate the isolation of plasma proteins - especially IVIgs - and significantly reducing process footprint, thus lowering the cost of therapy [23, 24]. This, however, requires the design of novel chromatographic tools and processes that combine high binding capacity and selectivity with scalability, affordability, and safety.

Our group has developed the concept of "flow-through affinity chromatography", wherein all the nontarget species in a complex feedstock are captured by peptide ligands immobilized on a chromatographic substrate (LigaGuard ${ }^{\mathrm{TM}}$ ), allowing the target protein product to flow through unbound $\left[{ }^{25}\right]$. A LigaGuard ${ }^{\mathrm{TM}}$ adsorbent tailored for the purification of therapeutic mAbs from Chinese Hamster Ovary $(\mathrm{CHO})$ cell culture harvests has been demonstrated in prior work $\left.{ }^{26,27}\right]$. In this study, a LigaGuard ${ }^{\mathrm{TM}}$ adsorbent tailored for IVIg purification from human plasma has been developed, whose peptide ligands bind all non-Ig plasma proteins. Our group has also developed a Ig-targeting peptide- [ $\left.{ }^{28}\right]$ and peptoid-based [ ${ }^{29-31}$ ] adsorbents (LigaTrap ${ }^{\mathrm{TM}}$ ), which have been demonstrated by purifying pIgG from different mammalian plasma as well as therapeutic mAbs from industrial cell culture fluids.

In this study, we implemented the pair of LigaGuard ${ }^{\mathrm{TM}}$ and LigaTrap ${ }^{\mathrm{TM}}$ adsorbents into a two-step process of chromatographic purification of polyclonal immunoglobulin $\mathrm{G}(\mathrm{IgG})$ from human plasma: the LigaGuard ${ }^{\mathrm{TM}}$ adsorbent operates in flow-through mode to capture plasma proteins, while LigaTrap ${ }^{\mathrm{TM}}$ isolates the $\operatorname{IgG}$ product in bind-and-elute mode. The buffer composition and $\mathrm{pH}$, the column loading, and residence time were optimized for both adsorbents to maximize product recovery and purity. Specifically, $20 \mathrm{mM}$ Bis-Tris $\mathrm{HCl}$ buffer at $\mathrm{pH} 5.5$ (Buffer A) was selected as running buffer for LigaGuard ${ }^{\mathrm{TM}}$, whereas $0.1 \mathrm{M}$ phosphate buffer at $\mathrm{pH} 7.4$ containing $0.5 \mathrm{M}$ sodium chloride and $25 \mathrm{mM}$ sodium caprylate (Buffer B) was selected as binding and washing buffer for LigaTrap ${ }^{\mathrm{TM}}$.

Two alternative processes were evaluated. The first design utilized a LigaGuard ${ }^{\mathrm{TM}}$ column for scrubbing 
plasma proteins prior to the IgG purification-and-concentration step using a LigaGuard ${ }^{\mathrm{TM}}$ column; the plasma diluted in Buffer A was fed to a LigaGuard ${ }^{\mathrm{TM}}$ column, the effluent was exchanged to Buffer B and loaded on a LigaTrap ${ }^{\mathrm{TM}}$ column, from which the $\mathrm{pIgG}$ produced was eluted with $63.8 \%$ global recovery and $99.7 \%$ purity, corresponding to a 2 -fold concentration and a 3.28 logarithmic removal value (LRV) of plasma proteins. For comparison, Protein $\mathrm{G}$ agarose afforded a $\sim 64 \%$ recovery and $\sim 97 \%$ purity alone, and $\sim 67 \%$ recovery and $\sim 97 \%$ purity when preceded by LigaGuard ${ }^{\mathrm{TM}}$. In the second design, the adsorbents were switched: the LigaTrap ${ }^{\mathrm{TM}}$ column was initially utilized to capture and concentrate pIgG from plasma; the eluted fraction was exchanged to Buffer A and fed to a LigaGuard ${ }^{\mathrm{TM}}$ column to polish the elution stream, affording $82.3 \%$ global recovery and $98.8 \%$ purity (3.41 LRV). Collectively, these results demonstrate the potential of a fully chromatographic process for purifying polyclonal IgG from plasma feedstocks.

\section{Experimental}

2.1. Materials. The Fmoc-Cys-(Trt)-Rink polystyrene resin was purchased from Anaspec (Fremont, CA, USA), Toyopearl AF-Amino-650M resin was obtained from Tosoh Corporation (Tokyo, Japan), and WorkBeads 40 ACT resin was from Bioworks (Uppsala, Sweden). Fmoc-N-[3-(N-Pbf-guanidino)-propyl]glycine was from PolyPeptide (Torrance, CA, USA). Fluorenylmethoxycarbonyl- (Fmoc-) protected amino acids Fmoc-Gly-OH, Fmoc-Ser(tBu)-OH, Fmoc-Ile-OH, Fmoc-Ala-OH, Fmoc-Phe-OH, Fmoc-Tyr(tBu)-OH, Fmoc-Asp(OtBu)-OH, Fmoc-His(Trt)-OH, Fmoc-Arg(Pbf)-OH, Fmoc-Lys(Boc)-OH, Fmoc-Asn(Trt)-OH, and Fmoc-Glu(OtBu)-OH, Hexafluorophosphate Azabenzotriazole Tetramethyl Uronium (HATU), diisopropylethylamine (DIPEA), piperidine, and trifluoroacetic acid (TFA) were obtained from ChemImpex International (Wood Dale, IL, USA). Kaiser test kits, triisopropylsilane (TIPS), and 1,2-ethanedithiol (EDT) were obtained from Millipore Sigma (St. Louis, MO, USA). N,N'-dimethylformamide (DMF), dichloromethane (DCM), methanol, and N-methyl-2-pyrrolidone (NMP) were obtained from Fisher Chemical (Hampton, NH, USA).

Human polyclonal Immunoglobulin G (IgG) in lyophilized form was purchased from Athens Research \& Technology, Inc (Athens, GA, USA). Ig-rich paste, and cryo-rich and cryo-poor human plasma were a gift of CSL Behring (King of Prussia, PA, USA). Sodium phosphate monobasic $\left(\mathrm{NaH}_{2} \mathrm{PO}_{4}\right)$, sodium phosphate dibasic $\left(\mathrm{Na}_{2} \mathrm{HPO}_{4}\right)$, hydrochloric acid, sodium hydroxide, Bis-Tris, ethanol, sodium chloride $(\mathrm{NaCl})$, and sodium caprylate (NaCapr) were purchased from Fisher Scientific (Hampton, NH, USA). Phosphate buffered saline at pH 7.4 was purchased from Millipore Sigma (St. Louis, MO, USA). Vici Jour PEEK chromatography columns (2.1 mm ID, $30 \mathrm{~mm}$ length, $0.1 \mathrm{~mL}$ volume), Altech chromatography columns (3.6 mm ID, $50 \mathrm{~mm}$ length, $0.5 \mathrm{~mL}$ volume), and $10 \mu \mathrm{m}$ polyethylene frits were obtained from VWR International (Radnor, PA, USA). The Yarra $3 \mu \mathrm{m}$ SEC-2000 $300 \times 7.8 \mathrm{~mm}$ size exclusion chromatography column was obtained from Phenomenex Inc. (Torrance, CA, USA). Protein G Sepharose ${ }^{\mathrm{TM}}$ Fast Flow resin was purchased from Millipore Sigma (Burlington, MA, USA). The 10-20\% Tris-Glycine HCl SDS-PAGE gels and Coomassie blue stain were purchased from Bio-Rad Life Sciences (Carlsbad, CA, USA). A Pierce BCA Protein Assay Kit was purchased from Fisher Scientific (Pittsburgh, PA, USA). All chromatographic experiments were performed using a Waters Alliance 2690 separations module system equipped with a Waters 2487 dual absorbance detector were purchased from Waters Corporation (Milford, MA, USA).

2.2. Preparation of LigaTrap ${ }^{\mathrm{TM}}$ Human IgG resin and LigaGuard ${ }^{\mathrm{TM}}$ resin. The peptoid ligand PL-16 was synthesized and conjugated to WorkBeads $40 \mathrm{ACT}$ resin as described in prior work (note: the conjugation strategy and the value of peptoid density on WorkBeads resin are proprietary information of LigaTrap Technologies LLC) [32, 33 ]. The resulting LigaTrap ${ }^{\mathrm{TM}}$ Human IgG resin was rinsed in water and stored in $20 \% \mathrm{v} / \mathrm{v}$ aqueous methanol for long-term storage. The peptide-based LigaGuard ${ }^{\mathrm{TM}}$ resin was produced by direct peptide synthesis on Toyopearl AF-Amino-650M resin via Fmoc/tBu strategy as described in prior work (note: the values of peptide density on Toyopearl resin are proprietary information of LigaTrap Technologies LLC) [ ${ }^{34}$ ], and stored in $20 \% \mathrm{v} / \mathrm{v}$ aqueous methanol for long-term storage.

2.3. Dynamic binding capacity of pure IgG on LigaTrap ${ }^{\mathrm{TM}}$ Human IgG resin. The dynamic binding capacity of LigaTrap ${ }^{\mathrm{TM}}$ Human IgG resin at $10 \%$ breakthrough of IgG $\left(D B C{ }_{10 \%}, \mathrm{mg} / \mathrm{mL}\right.$ resin) was measured as reported in prior studies $\left[{ }^{28,35-37}\right]$. A volume of $0.1 \mathrm{~mL}$ of LigaTrap ${ }^{\mathrm{TM}}$ Human IgG resin was wet packed in 
a Vici Jour PEEK column, washed with 10 column volumes (CVs) of $20 \% \mathrm{v} / \mathrm{v}$ ethanol, deionized water (3 $\mathrm{CVs}$ ), and finally equilibrated with $10 \mathrm{CVs}$ of PBS buffer at $\mathrm{pH} 7.4$. A volume of $2 \mathrm{~mL}$ of solution of human polyclonal IgG at either $5 \mathrm{mg} / \mathrm{mL}$ or $10 \mathrm{mg} / \mathrm{mL}$ in PBS buffer was continuously loaded on the column at the flow rate of either $0.05 \mathrm{~mL} / \mathrm{min}$ (residence time, RT: $2 \mathrm{~min}$ ) or $0.02 \mathrm{~mL} / \mathrm{min}$ (RT: $5 \mathrm{~min}$ ). Following load, the resin was washed with $10 \mathrm{CVs}$ of PBS buffer at the flow rate of $0.1 \mathrm{~mL} / \mathrm{min}$. IgG elution was then performed with $20 \mathrm{CVs}$ of $0.2 \mathrm{M}$ acetate buffer at $\mathrm{pH} 4.0$ at the flow rate of $0.2 \mathrm{~mL} / \mathrm{min}$. The resin was regenerated with $10 \mathrm{CVs}$ of $0.1 \mathrm{M}$ glycine buffer at $\mathrm{pH} 2.5$ at the flow rate of $0.2 \mathrm{~mL} / \mathrm{min}$. The effluents were continuously monitored by UV spectrometry at $280 \mathrm{~nm}$ and the resulting chromatograms were utilized to calculate the $D B C_{10 \%}$ of IgG.

2.4. Purification of IgG from Ig-rich paste, cryo-poor, and cryo-rich human plasma using LigaTrap ${ }^{\text {TM }}$ Human IgG resin in bind-and-elute mode. A volume of $0.1 \mathrm{~mL}$ of LigaTrap ${ }^{\mathrm{TM}}$ Human IgG resin was wet packed in a Vici Jour PEEK column, washed with $20 \% \mathrm{v} / \mathrm{v}$ ethanol $(10 \mathrm{CVs})$, deionized water $(3 \mathrm{CVs})$, and finally equilibrated with binding buffer $(10 \mathrm{CVs})$ at the flow rate of $0.2 \mathrm{~mL} / \mathrm{min}$. The following binding buffers were prepared:(i) X M NaCl in PBS at $\mathrm{pH} \mathrm{Y}$, wherein $\mathrm{X}$ is either $0,0.15,0.25$, or 0.5 , or $\mathrm{Y}$ is either

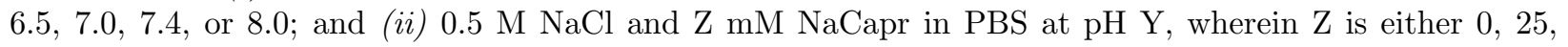
50 , or 75 , and $\mathrm{Y}$ is either 7.4 or 8.0. The Ig-rich paste was dissolved in the binding buffer to achieve a total protein concentration of $\sim 10 \mathrm{mg} / \mathrm{mL}$ by stirring the solution overnight at $4^{\circ} \mathrm{C}$; cryo-poor plasma was diluted in binding buffer to achieve a total protein titer of $25.7 \mathrm{mg} / \mathrm{mL}$ and an IgG titer of $7.4 \mathrm{mg} / \mathrm{mL}$; similarly, cryo-rich plasma was diluted in binding buffer to achieve a total protein titer of $30.0 \mathrm{mg} / \mathrm{mL}$ and an IgG titer of $7.0 \mathrm{mg} / \mathrm{mL}$; the feedstocks were filtered using $0.44 \mu \mathrm{m}$ and $0.22 \mu \mathrm{m}$ Millex-GP syringe filters (MilliporeSigma, Burlington, MA). A volume of either $0.2 \mathrm{~mL}$ of Ig-rich paste solution (corresponding to 1.5 $\mathrm{mg}$ of $\mathrm{IgG}$ ), $0.2 \mathrm{~mL}$ of cryo-poor plasma solution (1.5 $\mathrm{mg}$ of $\mathrm{IgG}$ ), or $0.2 \mathrm{~mL}$ of cryo-rich plasma solution (1.4 $\mathrm{mg}$ of $\operatorname{IgG}$ ) were loaded on the column at the flow rate of $0.02 \mathrm{~mL} / \mathrm{min}$ (RT: $5 \mathrm{~min}$ ). After washing the adsorbent with $10 \mathrm{CVs}$ of binding buffer at $0.1 \mathrm{~mL} / \mathrm{min}$, the bound IgG was eluted with $20 \mathrm{CVs}$ of 0.2 $\mathrm{M}$ acetate buffer at $\mathrm{pH} 4.0$ at $0.2 \mathrm{~mL} / \mathrm{min}$ and neutralized upon collection using $3 \mathrm{M}$ Tris buffer at $\mathrm{pH} 8.5$. The adsorbent was then regenerated with $10 \mathrm{CVs}$ of $0.1 \mathrm{M}$ glycine buffer at $\mathrm{pH} 2.5$ at $0.2 \mathrm{~mL} / \mathrm{min}$, cleaned in place with $10 \mathrm{CVs}$ of aqueous $0.1 \mathrm{M} \mathrm{NaOH}$, and finally equilibrated with binding buffer. The collected flow-through and elution fractions were analyzed by Protein G Sepharose ${ }^{\mathrm{TM}}$ Fast Flow resin to obtain IgG yield, and via size exclusion chromatography (SEC) and SDS-PAGE under reducing condition to obtain IgG purity.

2.5. Capture of non-Ig plasma proteins in flow-through mode by first- and second-generation LigaGuard ${ }^{\mathrm{TM}}$ adsorbents. The following mobile phases were prepared: $20 \mathrm{mM}$ piperazine $\mathrm{HCl}$ buffer at $\mathrm{pH} 5.0$ and 5.5; $20 \mathrm{mM}$ Bis-Tris $\mathrm{HCl}$ buffer at $\mathrm{pH} 5.5,6.0,6.5$, and 7.0; $20 \mathrm{mM}$ citric acid and $\mathrm{Na}_{2} \mathrm{HPO}_{4}$

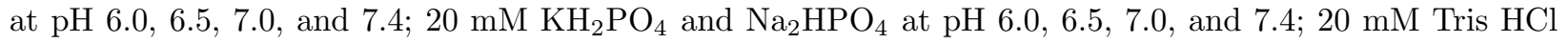
buffer at $\mathrm{pH} 7.0$ and 7.4; and PBS buffer at $\mathrm{pH} 7.4$. A volume of $0.5 \mathrm{~mL}$ of either first- or second-generation LigaGuard $^{\mathrm{TM}}$ resin was wet packed in a $0.5 \mathrm{~mL}$ Alltech PEEK column, washed with $20 \% \mathrm{v} / \mathrm{v}$ ethanol (10 CVs) and deionized water ( $3 \mathrm{CVs})$, and finally equilibrated with binding buffer (10 CVs) at the flow rate of $0.5 \mathrm{~mL} / \mathrm{min}$. Pure IgG solutions were prepared by dissolving human polyclonal IgG in the above-listed buffers at $2.5 \mathrm{mg} / \mathrm{mL}$. The Ig-depleted plasma samples were prepared as the flow-through fractions obtained by injecting $1.0 \mathrm{~mL}$ of cryo-rich plasma diluted 10-fold with the corresponding buffer in the columns packed with $1.0 \mathrm{~mL}$ HiTrap Protein A HP and $1.0 \mathrm{~mL}$ of HiTrap Protein G HP. A volume of $7 \mathrm{~mL}$ volume of either pure IgG solution or Ig-depleted diluted plasma (protein titer $\sim 5.0 \mathrm{mg} / \mathrm{mL}$ ) was continuously loaded on the LigaGuard ${ }^{\mathrm{TM}}$ column at the flow rate of $0.5 \mathrm{~mL} / \mathrm{min}$ (RT: $\left.1 \mathrm{~min}\right)$ and the flow-through fractions were collected at $0.5 \mathrm{~mL}$ increments; after loading, the column was washed with $20 \mathrm{CVs}$ of equilibration buffer, and a pooled wash fraction was collected until the $280 \mathrm{~nm}$ absorbance decreased below $50 \mathrm{mAU}$. The resin was discarded after one use (i.e., no elution or regeneration was performed). The collected fractions were analyzed by Pierce BCA Protein Assay Kit, Protein G Sepharose ${ }^{\mathrm{TM}}$ Fast Flow resin, size exclusion chromatography (SEC), and SDS-PAGE under reducing condition to obtain the breakthrough ratio (Equation 1 ), yield (Equation 2 ), and binding ( $\mathrm{mg}$ of protein per $\mathrm{mL}$ resin, Equation 3 ).

2.6. Purification of IgG from cryo-rich and cryo-poor human plasma using a 2-step chromatographic process 
comprising LigaGuard ${ }^{\mathrm{TM}}$ and LigaTrap ${ }^{\mathrm{TM}}$ resins. LigaGuard ${ }^{\mathrm{TM}}$ and LigaTrap ${ }^{\mathrm{TM}}$ resin were wet packed in three $0.5 \mathrm{~mL}$ Alltech PEEK columns, and washed with $20 \% \mathrm{v} / \mathrm{v}$ ethanol $(10 \mathrm{CVs})$ and deionized water $(3$ CVs). The LigaGuard ${ }^{\mathrm{TM}}$ resin were equilibrated with $10 \mathrm{CVs}$ of $20 \mathrm{mM}$ Bis-Tris $\mathrm{HCl}$ buffer either at $\mathrm{pH}$ 6.0 or 5.5 (Buffer A), while the LigaTrap ${ }^{\mathrm{TM}}$ resin was equilibrated with $10 \mathrm{CVs}$ of $0.1 \mathrm{M}$ phosphate buffer at $\mathrm{pH} 7.4$ containing $0.5 \mathrm{M} \mathrm{NaCl}$ and $25 \mathrm{mM}$ NaCapr (Buffer B). Diluted plasma, prepared as described in Section 2.4, was loaded on the LigaGuard ${ }^{\mathrm{TM}}$ column at the flow rate of $0.5 \mathrm{~mL} / \mathrm{min}$ (RT: $1 \mathrm{~min}$ ), and the flow-through fractions were collected at $0.5 \mathrm{~mL}$ increments; the loading was chased with $20 \mathrm{CVs}$ of $0.2 \mathrm{M}$ acetate buffer at $\mathrm{pH} 5.0$ (Buffer C). The IgG-rich effluent collected during loading and buffer chasing was continuously mixed with Buffer B and injected on the LigaTrap ${ }^{\mathrm{TM}}$ column. Column loading and washing, IgG elution, and column regeneration and cleaning were performed as detailed in Section 2.5 . The collected flow-through and elution fractions were analyzed by Protein G Sepharose ${ }^{\mathrm{TM}}$ Fast Flow resin to obtain $\operatorname{IgG}$ yield, and via size exclusion chromatography (SEC) and SDS-PAGE under reducing condition to obtain IgG purity.

2.7. Quantification of IgG yield by analytical Protein G chromatography. The IgG concentration in the collected fractions were determined by analytical Protein G chromatography using a Waters Alliance 2690 separations module system with a Waters 2487 dual absorbance detector (Waters Corporation, Milford, MA, USA). Protein G Sepharose ${ }^{\mathrm{TM}}$ Fast Flow resin wet packed in a Vici Jour PEEK $2.1 \mathrm{~mm}$ ID x $30 \mathrm{~mm}$ column $(0.1 \mathrm{~mL})$ was equilibrated with PBS, $\mathrm{pH}$ 7.4. A volume of $50 \mu \mathrm{L}$ for each sample or standard was injected, and the analytical method proceeded as outlined in Table $\mathbf{1}$. The effluent was monitored by 280 $\mathrm{nm}$ absorbance (A280), and the concentration was determined based on the peak area of the A280 elution peak. Pure IgG at $0,0.1,0.5,1.0,2.0,4.0,6.0,8.0$, and $10.0 \mathrm{mg} / \mathrm{mL}$ was utilized to construct the standard curve.

Table 1. HPLC method for IgG quantification by analytical Protein G chromatography.

\begin{tabular}{llll}
\hline Time $(\mathbf{m i n})$ & Flowrate $(\mathbf{m L} / \mathbf{m i n})$ & \% Buffer A & \% Buffer B \\
\hline 0.00 & 0.5 & $100 \%$ & $0 \%$ \\
2.00 & 0.5 & $100 \%$ & $0 \%$ \\
2.01 & 0.5 & $0 \%$ & $100 \%$ \\
6.00 & 0.5 & $0 \%$ & $100 \%$ \\
6.01 & 0.5 & $100 \%$ & $0 \%$ \\
10.00 & 0.5 & $100 \%$ & $0 \%$ \\
\hline
\end{tabular}

To assess the breakthrough ratio $\left(\mathrm{C} / \mathrm{C}_{0}\right)$, yield $(Y, \%)$ and binding capacity $(Q, \mathrm{mg} / \mathrm{mL}$ resin) of $\operatorname{IgG}$ product, the values of fractional breakthrough ratio, pooled yield, and protein binding as a function of $\mathrm{CV}$ were calculated usingEquations $\mathbf{1}-\mathbf{3}$, respectively.

Equation $1 C / C_{0}$ fractional, $x=\frac{C_{I g G, x}}{C_{I g G, L}}$

Equation $2 Y(\%)_{\text {pooled, } x}=\frac{\sum_{x=1}^{N} C_{I g G, x} \times V_{x}}{C_{I g G, L} \times \mathrm{V}_{L}} \times 100 \%$

Equation $3 Q(m g / m L \text { resin })_{\text {pooled, } x}=\frac{\sum_{x=1}^{N}\left(C_{I g G, L}-C_{I g G, x}\right) \times V_{x}}{V_{R}}$

Wherein $\mathrm{C} / \mathrm{C}_{0}(\%)_{\text {fractional, } \mathrm{x}}$ is the fractional IgG breakthrough ratio at fraction $\mathrm{x}, \mathrm{Y}(\%)_{\text {pooled, } \mathrm{x}}$ is the pooled IgG yield at fraction $\mathrm{x}, \mathrm{Q}(\mathrm{mg} / \mathrm{mL} \text { resin })_{\text {pooled, } \mathrm{x}}$ is the pooled binding capacity in at fraction $\mathrm{x}, \mathrm{C}_{\operatorname{IgG}, \mathrm{x}}$ is the IgG concentration in fraction $x, V_{x}$ is the volume of fraction $x, C_{I g G, L}$ is the $\operatorname{IgG}$ concentration in the load samples, and $\mathrm{V}_{\mathrm{L}}$ is the cumulative feed volume loaded, and $\mathrm{N}$ is the number of fractions generated by loading $\mathrm{V}_{\mathrm{L}}$, and $\mathrm{V}_{\mathrm{R}}$ is the volume of selected resin.

To assess the breakthrough performance of non-immunoglobulin proteins, the corresponding values were calculated using Equation $\mathbf{1}-\mathbf{3}$, respectively. 
2.8. Quantification of IgG purity by size-exclusion chromatography (SEC). The collected fractions were then analyzed by analytical SEC using a Yarra $3 \mu \mathrm{m}$ SEC-2000 $300 \mathrm{~mm}$ x $7.8 \mathrm{~mm}$ column operated with a 40-min isocratic method using PBS at pH 7.4 as mobile phase. A volume of $50 \mu \mathrm{L}$ of sample was injected and the effluent continuously monitored by UV spectrometry at $280 \mathrm{~nm}$ absorbance (A280). The fractional purity of $\operatorname{IgG}(\mathrm{P}, \%)$ was calculated usingEquation 4 .

Equation $4 P(\%)_{\text {fractional }, x}=\frac{A_{I g G, x}}{A_{I g G, x}+A_{\text {impurity }, x}} \times 100 \%$

Wherein $\mathrm{P}(\%)_{\text {fractional, } \mathrm{x}}$ is the fractional $\operatorname{IgG}$ purity at fraction $\mathrm{x}, \mathrm{A}_{\operatorname{IgG}, \mathrm{x}}$ is the $\operatorname{IgG}$ peak area in the $\mathrm{x}$-th fraction, $\mathrm{A}_{\text {impurity, } \mathrm{x}}$ is the impurity peak area in the $\mathrm{x}$-th fraction.

2.9. Quantification of IgG purity by sodium dodecyl polyacrylamide gel electrophoresis (SDS-PAGE). The collected fractions were analyzed by SDS-PAGE using 4-20\% Mini-PROTEAN ${ }^{\mathrm{TM}}$ TGX Precast protein gels with Tris/Glycine/SDS buffer as running buffer. The fractions were diluted or concentrated to a total protein concentration of $\sim 1 \mathrm{mg} / \mathrm{mL}$ and a volume of $10 \mu \mathrm{L}$ of different samples were loaded to the wells of SDS-PAGE gels. The sample stripes were concentrated under $80 \mathrm{~V}$ for about $30 \mathrm{~min}$ and separated under $120 \mathrm{~V}$ for about $1 \mathrm{~h}$. Then the gels were stained by Coomassie Brilliant Blue R-250 Staining solution for about 25 min and then distained using $10 \%$ glacial acetic acid, $5 \%$ ethanol dissolved in Milli-Q water. Finally, the stained protein strips were imagined by the Gel Doc2000 imaging system from Bio-Rad.

\section{Results and Discussion}

\subsection{IgG purification from human Ig-rich paste using LigaTrap ${ }^{\mathrm{TM}}$ resin}

LigaTrap $^{\mathrm{TM}}$ resin has been developed by our team for purifying $\gamma$-globulins from polyclonal and monoclonal sources. This affinity adsorbent has been used by purifying (i) pIgG from a variety of mammalian sources, including the human, rodent (mouse, rat, and rabbit), caprine (goat and sheep), equine (horse and donkey), camelid (camel and llama); (ii) human monoclonal IgG, IgA, and IgM from Chinese Hamster Ovary (CHO) and Human Embryonic Kidney (HEK) cell culture supernatants [ ${ }^{33,}{ }^{38}$ ]; and(iii) avian IgY [ ${ }^{39}$ ]. Compared to Protein A/G-based adsorbents, the LigaTrap ${ }^{\mathrm{TM}}$ resin features comparable binding capacity and selectivity, improved lifetime [ $\left.{ }^{32}\right]$, and a substantially lower cost, making it ideal for the chromatographic extraction of pIgG from large volumes of pooled plasma.

In this study, we initially evaluated the performance of LigaTrap ${ }^{\mathrm{TM}}$ resin against a human Ig-rich paste obtained via cold ethanol precipitation of plasma. To this end, we optimized the process conditions focusing on protein loading (mass of IgG loaded per volume of resin), residence time (Figure S1 ), and composition (sodium chloride and sodium caprylate), concentration $(0,0.15,0.25$ and $0.5 \mathrm{M}$ of $\mathrm{NaCl}$ ), and $\mathrm{pH}(6.5,7.0$, 7.4 and 8.0) of the binding and washing buffers. The eluted fractions, obtained at $\mathrm{pH} 4.0$, were analyzed via analytical Protein G HPLC to determine pIgG adsorption and yield (Figured 1A and 1B ), and size exclusion chromatography (SEC, Figure 2C ) and gel electrophoresis to determine product purity in the eluted fractions (Figure 2 ).

\section{Hosted file}

image1.emf available at https://authorea.com/users/425045/articles/529963-purification-ofpolyclonal-immunoglobulin-g-from-human-serum-using-ligaguardtm-and-ligatraptm-adsorbents

Figure 1. Values of $(\boldsymbol{A})$ pIgG adsorption ( $m g$ of pIgG per $m L$ of LigaTrap ${ }^{T M}$ resin),(B) elution yield (\%), and (C) $p I g G$ purity in the eluted fraction (\%) obtained by purifying $\mathrm{pIg} G$ from anIg-rich paste using LigaTrap ${ }^{T M}$ resinand binding buffers with different $\mathrm{pH}(6.5,7.0,7.4$, and 8.0) and $\mathrm{NaCl}$ concentrations $(0,0.15,0.25$, and $0.5 \mathrm{M})$.

\section{Hosted file}

image2.emf available at https://authorea.com/users/425045/articles/529963-purification-ofpolyclonal-immunoglobulin-g-from-human-serum-using-ligaguardtm-and-ligatraptm-adsorbents 
Figure 2. SDS-PAGE analysis (reducing conditions, Coomassie staining) of the chromatographic fractions obtained by purifying $\mathrm{pIg} G$ from an Ig-rich paste using LigaTrap ${ }^{T M}$ resin and binding buffers with different pH: (A) 6.5,(B) 7.0, (C) 7.4, and (D) 8.0, and sodium chloride concentrations $(0,0.15$, 0.25, and 0.5 $M)$. Labels: $M W$, molecular weight marker; $h I g G$, human polyclonal IgG standard; F, feedstock obtained by dissolving the Ig-rich paste in binding buffer; FT-X, flow-through fraction obtained by loading Ig-rich paste diluted in a binding buffer with XM sodium chloride concentration; E-X, elution fraction obtained by loading Ig-rich paste diluted in a binding buffer with XM sodium chloride concentration; HSA, human serum albumin; $\operatorname{Ig} G H C$, heavy chain of $\operatorname{Ig} G$; $\operatorname{Ig} G L C$, light chain of $\operatorname{Ig} G$.

As shown in Figure 1, the value of $\mathrm{pH}$ in the binding buffer is the major determinant of pIgG binding strength and selectivity on LigaTrap ${ }^{\mathrm{TM}}$ resin; conversely, the value of $\mathrm{NaCl}$ concentration has a rather minor influence on product capture and purity. At all values of salinity, in fact, pIgG binding and yield continuously increased as the binding $\mathrm{pH}$ ranged from 6.5 to 8.0. Specifically, pIgG binding and elution yield reached their maximum of $\sim 11.4 \mathrm{mg} / \mathrm{mL}$ at $\mathrm{pH} 7.4$ and $\sim 99.0 \%$ at $\mathrm{pH} 8.0$, respectively; conversely, within each value of binding $\mathrm{pH}$, both binding and yield remained constant as the $\mathrm{NaCl}$ concentration increased, demonstrating that LigaTrap ${ }^{\mathrm{TM}}$ resin features salt-tolerant adsorption of $\mathrm{pIgG}$. These results are coherent with the chemical make-up of the LigaTrap ligand, which features a combination of hydrophobic (indolyl and isopropyl), cationic (pyridinyl and guanidyl), and hydrogen bond-forming (guanidyl and backbone amides) moieties [ $\left.{ }^{32}\right]$. As the isoelectric point of pIgG varies in the range $7.0-8.1[40,41]$, it stands to reason that binding is highest at 7.4, being driven mainly by hydrophobic and hydrogen bond interactions, which provide for salt-tolerant binding; as the $\mathrm{pH}$ is lowered to 4, elution is triggered by the electrostatic repulsion between the induced cationic charges on the pIgG and the ligand. While being a key driver of binding, the hydrophobic interactions do not compromise the selectivity of pIgG: ligand binding, which increases the purity of the target product 2 -fold, from $\sim 43 \%$ in the feedstock to $\sim 90 \%$ in the eluted fraction. When column loading is conducted at low salinity (i.e. , up to $0.15 \mathrm{M} \mathrm{NaCl}$ ), the purity of eluted pIgG shows a decreasing trend with $\mathrm{pH}$. This is imputed to anionic plasma proteins, such as $\alpha_{1}$-antitrypsin (pI 4.6), albumin (pI $~$ 4.7), fibrinogen $(\mathrm{pI} \sim 5.5)$, and transferrin $(\mathrm{pI} \sim 6)\left[4^{2}\right]$, which acquire a strong binding drive towards the cationic moieties of the ligand as the $\mathrm{pH}$ increases. This, however, can be effectively mitigated by increasing the conductivity of the binding and washing buffers: as the $\mathrm{NaCl}$ concentration is increased to $0.5 \mathrm{M}$, in fact, the pIgG purity in the eluted fraction is consistently at $90 \%$. These results are visually concerned by the electrophoretic analysis of the chromatographic fractions reported inFigure 2: (i) as the $\mathrm{pH}$ and the conductivity of the binding buffer increase, the presence of $\mathrm{pIgG}$ in the flow-through fraction decreases, while the amount of non-Ig plasma proteins increases; (iii) at $\mathrm{pH} 7.0$, the purity of $\mathrm{pIgG}$ in the eluted fraction is the highest across all values of binding conductivity. Overall, binding at higher conductivity effectively prevents electrostatic binding of non-Ig plasma proteins and promotes the hydrophobic component of IgG adsorption, affording high product capture, yield ([?] 85.0\%), and purity ( $90.0 \%)$. Accordingly, we adopted $\mathrm{NaCl}$ concentration of $0.5 \mathrm{M}$ in both binding and washing buffer for the remainder of this study.

To further improve the performance of the LigaTrap ${ }^{\mathrm{TM}}$ resin for its final implementation in the proposed 2step process, we evaluated the addition of sodium caprylate to minimize the capture of the highly abundant non-Ig serum proteins, chiefly albumin. Accordingly, new feedstock solution was prepared by dissolving the Ig-rich paste in different buffers prepared by adjusting a base aqueous solution of $0.1 \mathrm{M}$ phosphate and 0.5 $\mathrm{M} \mathrm{NaCl}$ at different values of $\mathrm{pH}$ (7.4 or 8.0) and sodium caprylate concentration $(0,25,50$, or $75 \mathrm{mM})$. The key chromatographic results - namely, pIgG binding, and elution yield and purity - are summarized inFigure 3, while the electrophoretic analysis of the collected fractions is reported in Figure 4 .

\section{Hosted file}

image3.emf available at https://authorea.com/users/425045/articles/529963-purification-ofpolyclonal-immunoglobulin-g-from-human-serum-using-ligaguardtm-and-ligatraptm-adsorbents

Figure 3. Values of (A) pIgG adsorption ( $m g$ of $p I g G$ per $m L$ of LigaTrap ${ }^{T M}$ resin), (B) elution yield $(\%)$, and $(C)$ pIgG purity in the eluted fraction (\%) obtained by purifying pIgG from an Ig-rich paste using LigaTrap ${ }^{T M}$ resin and binding buffers with different $p H(7.4$ and 8.0) and sodium caprylate concentrations 
(0, 25, 50 and $75 \mathrm{mM})$, and constant $\mathrm{NaCl}$ concentration (0.5 M).

\section{Hosted file}

image4.emf available at https://authorea.com/users/425045/articles/529963-purification-ofpolyclonal-immunoglobulin-g-from-human-serum-using-ligaguardtm-and-ligatraptm-adsorbents

Figure 4. SDS-PAGE analysis (reducing conditions, Coomassie staining) of the chromatographic fractions obtained by purifying $\mathrm{pIg} G$ from an Ig-rich paste using LigaTrap ${ }^{T M}$ resin and binding buffers with $p H$ of either $(\boldsymbol{A}) 7.4 \operatorname{or}(\boldsymbol{B})$ 8.0, and sodium caprylate concentrations (0, 25, 50 and $75 \mathrm{mM})$, and constant $\mathrm{NaCl}$ concentration $(0.5 \mathrm{M})$. Labels: $M W$, molecular weight marker; hIgG, human polyclonal IgG standard; F, feedstock obtained by dissolving the Ig-rich paste in binding buffer; FT-X, flow-through fraction obtained by loading Ig-rich paste diluted in a binding buffer with XM sodium caprylate concentration; E-X, elution fraction obtained by loading Ig-rich paste diluted in a binding buffer with XM sodium caprylate concentration; $H S A$, human serum albumin; IgG HC, heavy chain of IgG; IgG LC, light chain of IgG.

Notably, the addition of caprylate to the binding and washing buffers substantially reduced the amount of bound non-Ig plasma proteins, bringing the purity of $\mathrm{pIgG}$ in the elution from ${ }^{\sim} 90 \%$ (no caprylate) to $94 \%$ (75 mM caprylate and $\mathrm{pH} 8.0$ ); the rejection of albumin in particular is evident in the electrophoretic analysis of the flow-through fractions collected at pH 8.0 (Figure 4 ). At the same time, however, the addition of caprylate increases the strength of $\operatorname{IgG}$ adsorption, bringing the yield of $\mathrm{pIgG}$ in the elution from $\sim 99 \%$ (no caprylate) to $64 \%$ ( $75 \mathrm{mM}$ caprylate and $\mathrm{pH} 8.0$ ). In this regard, we speculate that, as the concentration of sodium caprylate in the binding buffer increases, the caprylate anions progressively saturate the binding sites on albumin and other plasma proteins, eventually adsorbing on IgG and increasing the effective hydrophobicity of its surface; this trend has been observed in prior work using the mixed-mode resin MEP HyperCel [43 ], where it was shown to increase the purity of pIgG at the cost of yield. Overall, column loading at $\mathrm{pH} 7.4$ afforded values of yield that are significantly and consistently higher ( $~ 95-100 \%)$ than those obtained by loading at $\mathrm{pH} 8.0(\sim 63-83 \%)$. Considering the high yield $(\sim 95 \%)$ and purity $(\sim$ $91 \%$ ), $0.1 \mathrm{M}$ phosphate buffer at $\mathrm{pH} 7.4$ added with $0.5 \mathrm{M} \mathrm{NaCl}$ and $25 \mathrm{mM}$ sodium caprylate was selected as binding and washing buffer for the remainder of this study.

\subsection{Purification of pIgG from cryo-rich and cryo-poor plasma in flow-through mode using LigaGuard adsorbents}

The LigaGuard ${ }^{\mathrm{TM}}$ adsorbent has been originally developed by our team as a combination of resins functionalized with multi-modal peptides for purifying monoclonal antibodies (mAbs) in flow-through mode from recombinant sources $[44-46]$. The ensemble of ligands is capable of capturing a broad spectrum of protein impurities while allowing the antibody product to flow through unbound. The multi-modal character of the peptides provides them with the ability to capture hundreds of protein contaminants that encompass a broad range of amino acid composition, post-translational modification, size, and concentration.

In this study, the LigaGuard ${ }^{\mathrm{TM}}$ adsorbent was utilized for the first time for IgG purification from a polyclonal source. However, the higher complexity of plasma, where the ratio of Igvs. non-Ig proteins is about 1:5 $\left[{ }^{47}\right]$, compared to that of recombinant sources, where the same ratio varies between 5:1 and 10:1 [48-50 ], required an optimization of both the composition of the LigaGuard ${ }^{\mathrm{TM}}$ ligands and the chromatographic protocol.

First, the chromatographic process was optimized by evaluating the effect of composition and $\mathrm{pH}$ of the running buffer on the recovery of $\mathrm{pIgG}$ and the retention of non-Ig plasma proteins. To this end, $20 \mathrm{mM}$ piperazine $\mathrm{HCl}$ buffer at $\mathrm{pH} 5.0$ and 5.5; $20 \mathrm{mM}$ Bis-Tris $\mathrm{HCl}$ buffer at $\mathrm{pH} 5.5,6.0,6.5$, and 7.0; $20 \mathrm{mM}$ citric acid and $\mathrm{Na}_{2} \mathrm{HPO}_{4}$ at $\mathrm{pH} 6.0,6.5,7.0$, and 7.4; $20 \mathrm{mM} \mathrm{KH}_{2} \mathrm{PO}_{4}$ and $\mathrm{Na}_{2} \mathrm{HPO}_{4}$ at $\mathrm{pH} \mathrm{6.0,6.5,} \mathrm{7.0,} \mathrm{and} \mathrm{7.4;}$ $20 \mathrm{mM}$ Tris $\mathrm{HCl}$ buffer at $\mathrm{pH} 7.0$ and 7.4; and PBS buffer at $\mathrm{pH} 7.4$ were evaluated as buffers. Injections of either pure human pIgG $(\sim 3.0 \mathrm{mg} / \mathrm{mL})$ or Ig-depleted plasma $(\sim 5.0 \mathrm{mg} / \mathrm{mL})$ were performed to select a value of protein load and a binding condition that hold the highest promise towards pIgG purification from plasma in flow-through mode. Following prior work with LigaGuard ${ }^{\mathrm{TM}}$ adsorbent, the residence time was 
set at $1 \mathrm{~min}$ to ensure fast processing of plasma and minimize processing time.

The resultant profiles of pIgG yield ( $\left.Y_{p I g G}\right) v s$. loading volume are collated in Figure $\mathbf{5}$; the corresponding values of breakthrough ratio, namely ratio of $\mathrm{pIgG}$ titer in the effluent vs. feedstock $\left(C_{p I g G} / C_{p I g G}{ }^{*}\right)$, and binding $\left(Q_{p I g G}\right)$ are reported in Figures $\mathbf{S 4 A}$ andS4B , respectively. The profiles of non-Ig plasma proteins capture $\left(Q_{P P}\right)$ vs. loading volume are collated in Figure $\mathbf{6}$, while the corresponding values of breakthrough ratio $\left(C_{P P} / C_{P P}{ }^{*}\right)$ are reported in Figure $\mathbf{S 4 C}$. By highlighting the role of buffer composition and $\mathrm{pH}$ on the binding of plasma proteins, these results corroborate the classification of the LigaGuard ${ }^{\mathrm{TM}}$ peptides as advanced multi-modal ligands. As observed in prior work, the $\mathrm{pH}$ is the most critical parameter in determining binding capacity and selectivity: decreasing $\mathrm{pH}$, in fact, consistently improved binding selectivity by concurrently increasing $Y_{p I g G}$ and $Q_{P P}$. Specifically, at the loading volume of $5 \mathrm{~mL}$ - corresponding to 10 column volumes $(\mathrm{CVs})$ - at which the LigaGuard ${ }^{\mathrm{TM}}$ adsorbent has reached saturation on non-Ig plasma proteins - decreasing the loading $\mathrm{pH}$ from 7.4 to 5.5 improved $Y_{p I g G}$ from $\sim 35.0 \%$ to $\sim 80.0 \%$. These results can be directly tied to the isoelectric point of both $\mathrm{pIgG}$ and the LigaGuard ${ }^{\mathrm{TM}}$ peptides: as the environment becomes more acidic, both the ligands $(\mathrm{pI}=7.8-12.5)\left[{ }^{51}\right]$ and $\mathrm{pIgG}(\mathrm{pI}=6.1-8.5)\left[{ }^{40,}{ }^{41}\right]$ acquire a net positive charge, and undesired pIgG capture is prevented by electrostatic repulsion.

\section{Hosted file}

image5.emf available at https://authorea.com/users/425045/articles/529963-purification-ofpolyclonal-immunoglobulin-g-from-human-serum-using-ligaguardtm-and-ligatraptm-adsorbents

Figure 5. Profiles of $\mathrm{pIg} G$ flow-through yield $\left(Y_{p I g G}\right)$ vs. loading volume obtained by injecting a solution of pIgG at $3 \mathrm{mg} / \mathrm{mL}$ in different binding buffers: $(\boldsymbol{A}) 20 \mathrm{mM}$ piperazine $\mathrm{HCl}$ buffer at $\mathrm{pH} 5.0$ and 5.5; $20 \mathrm{mM}$ Bis-Tris $\mathrm{HCl}$ buffer at pH5.5; (B) $20 \mathrm{mM}$ citric acid and $\mathrm{Na}_{2} \mathrm{HPO}_{4}, \mathrm{KH}_{2} \mathrm{PO}_{4}$ and $\mathrm{Na}_{2} \mathrm{HPO}_{4}$, and Bis-Tris $\mathrm{HCl}$ buffer at $\mathrm{pH}$ 6.0; (C) $20 \mathrm{mM}$ citric acid and $\mathrm{Na}_{2} \mathrm{HPO}_{4}, \mathrm{KH}_{2} \mathrm{PO}_{4}$ and $\mathrm{Na}_{2} \mathrm{HPO}_{4}$, and Bis-Tris $\mathrm{HCl}$ buffer at pH 6.5; (D) $20 \mathrm{mM}$ citric acid and $\mathrm{Na}_{2} \mathrm{HPO}_{4}, \mathrm{KH}_{2} \mathrm{PO}_{4}$ and $\mathrm{Na}_{2} \mathrm{HPO}_{4}$, Bis-Tris $\mathrm{HCl}$, and Tris $\mathrm{HCl}$ buffer at $\mathrm{pH} 7.0$; and (E) $20 \mathrm{mM}$ citric acid and $\mathrm{Na}_{2} \mathrm{HPO}_{4}, \mathrm{KH}_{2} \mathrm{PO}_{4}$ and $\mathrm{Na}_{2} \mathrm{HPO}_{4}$, Tris $\mathrm{HCl}$ buffer at $p H$ \%.4, and PBS buffer at $p H 7.4$ - on first-generation LigaGuard ${ }^{T M}$ resin.

Compared to $\mathrm{pH}$, buffer composition has a minor, yet still noticeable effect on pIgG yield. In particular, as the $\mathrm{pH}$ decreases, differences in ionic strength - determined by both concentration and valency of the ions - result in different profiles of $\mathrm{Y}_{\mathrm{pIg}}$ vs.loading volume. At $\mathrm{pH}$ 7.4, in fact, the values of $\mathrm{Y}_{\mathrm{pIgG}} \mathrm{obtained}$

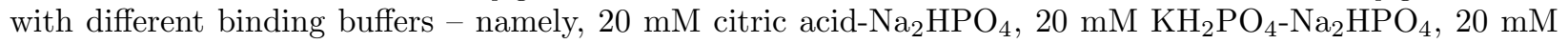
Tris $\mathrm{HCl}$, and $\mathrm{PBS}$ - are virtually indistinguishable; at $\mathrm{pH} 6.5-7.0$, a $10 \%$ difference in $\mathrm{Y}_{\mathrm{pIgG}}$ across the entire range of loading volume is observed between the monovalent Bis-Tris $\mathrm{HCl}$ buffer and the trivalent citric acid- $\mathrm{Na}_{2} \mathrm{HPO}_{4}$ buffer; as the $\mathrm{pH}$ decreases further to 5.0 - 6.0, the difference in $Y_{p I g G}$ among the various buffers grows to $20 \%$, with piperazine $\mathrm{HCl}$ buffer at $\mathrm{pH} 5.0$ affording the highest product yield in flowthrough mode, namely $87 \%$ at the cut-off loading volume of $5 \mathrm{~mL}(10 \mathrm{CVs})$. The capture of pIgG during the initial stages of binding - namely, up to a loading volume of $1.5 \mathrm{~mL}(3 \mathrm{CVs})$ - is due to the makeup of the load: in the absence of non-Ig proteins competing with pIgG for the peptide ligands, a small product loss due to non-specific adsorption is inevitable. In this context, it is also important to notice that $\mathrm{Y}_{\mathrm{pIg}}$ can be increased by "chasing" the loading with buffer C; for example, $\mathrm{Y}_{\mathrm{pIgG}}$ rose from $75 \%$ to $87 \%$ when the loading was followed by flowing $20 \mathrm{mM}$ Bis-Tris $\mathrm{HCl}$ buffer at $\mathrm{pH}$ 6.0, and rose from $77 \%$ to $87 \%$ when the followed by flowing $20 \mathrm{mM}$ piperazine $\mathrm{HCl}$ buffer at $\mathrm{pH}$ 5.5. While operating binding under acidic conditions reduced the loss of $\mathrm{pIgG}$, we resolved not to explore any buffer with $\mathrm{pH}<5.0$; operating at lower $\mathrm{pH}$, in fact, would likely result in a significant flow-through of albumin ( $\left.\mathrm{pI} \sim 4.7^{52-54}\right)$ and increase the risk of $\mathrm{pIgG}$ denaturation and aggregation 55,56. Accordingly, we adopted $20 \mathrm{mM}$ Bis-Tris $\mathrm{HCl}$ buffer at $\mathrm{pH} 6.0$ and 5.5 as well as $20 \mathrm{mM}$ piperazine $\mathrm{HCl}$ buffer at $\mathrm{pH} 5.5$ and 5.0 as buffers for pIgG purification from human plasma in flow-through mode in the remainder of this study.

Next, the capture of non-Ig plasma proteins by the LigaGuard adsorbent was evaluated. A feedstock comprising of filtered and Ig-depleted plasma with a protein titer of $\sim 6.0 \mathrm{mg} / \mathrm{mL}$ was injected at the residence time of $1 \mathrm{~min}$; the protein titer in the effluent fractions, collected at $0.5 \mathrm{~mL}$ increments, was measured to 
determine the profiles of non-Ig plasma proteins capture $\left(Q_{P P}\right) v s$. loading volume (Figure 6 ).

\section{Hosted file}

image6.emf available at https://authorea.com/users/425045/articles/529963-purification-ofpolyclonal-immunoglobulin-g-from-human-serum-using-ligaguardtm-and-ligatraptm-adsorbents

Figure 6. Profiles of non-Ig plasma protein capture $\left(Q_{P P}\right)$ vs. loading volume obtained by injecting diluted Ig-depleted plasma at $6 \mathrm{mg} / \mathrm{mL}$ in different binding buffers - namely, $20 \mathrm{mM}$ piperazine $\mathrm{HCl}$ buffer at $\mathrm{pH}$ 5.0 and 5.5; $20 \mathrm{mM}$ Bis-Tris $\mathrm{HCl}$ buffer at $p H 5.5$ and 6.0; and PBS buffer at $p H$ 7.4 - on LigaGuard ${ }^{T M}$ resin.

When operating at $\mathrm{pH}$ 7.4, substantial flow-through of non-Ig plasma proteins was observed: as soon as the loading a volume of $\sim 1-1.5 \mathrm{~mL}(2-3 \mathrm{CVs})$ was reached, until which notable capture was observed, the $C_{P P} / C_{P P}$ * rapidly rose to $\sim 0.8$; combined with product loss discussed above, these results disqualified PBS as a mobile phase for flow-through purification of pIgG using the LigaGuard. To some surprise, loading in $20 \mathrm{mM}$ piperazine- $\mathrm{HCl}$ buffers at $\mathrm{pH} 5.0$ and 5.5 failed to afford appreciable capture of plasma proteins; for example, at the loading volume of $2.0 \mathrm{~mL}(4 \mathrm{CVs})$ and $\mathrm{pH} 5.5$, the breakthrough curves of both $\mathrm{pIgG}$ and plasma proteins overlapped, resulting in a $Y_{p I g G}$ of $59 \%$ and a $Q_{P P}$ of $10.7 \mathrm{mg}$ per $\mathrm{mL}$ of resin. Accordingly, piperazine- $\mathrm{HCl}$ was excluded as a buffer for LigaGuard flow-through operation. Conversely, loading in BisTris buffers at $\mathrm{pH} 5.5$ or 6.0 led to a notable increase in the capture of non-Ig plasma proteins: at the loading volume of $1 \mathrm{~mL}\left(2 \mathrm{CVs}\right.$ ), the $Y_{p I g G}$ reached $50 \%$ while only $4 \%$ of the loaded non-Ig plasma proteins are found in the effluent, corresponding to a $Q_{P P}$ of $8.9 \mathrm{mg} / \mathrm{mL}$; at the cut-off value of loading $(10 \mathrm{CVs})$, the $Y_{p I g G}$ reached $80 \%$ and approximately $53.1 \%$ of the non-Ig plasma proteins has been captured, corresponding to a $Q_{P P}$ of $\sim 23.7 \mathrm{mg} / \mathrm{mL}$. The profile of $Q_{P P}$ reached a plateau value of $25 \mathrm{mg} / \mathrm{mL}$ at a loaded volume between $4-5 \mathrm{~mL}(8-10 \mathrm{CVs})$, which is coherent with what observed in prior work on the flow-through capture of CHO HCPs using the LigaGuard adsorbent. As no appreciable differences in $Y_{p I g G}$ and $Q_{P P}$ were found between the effluents obtained with Bis-Tris buffers at $\mathrm{pH} 5.5$ and $\mathrm{pH}$ 6.0, the latter was adopted as binding buffer for subsequent studies of flow-through purification of pIgG from whole human plasma.

Capitalizing on these results, we evaluated the LigaGuard adsorbent for the flow-through purification of pIgG from cryo-rich plasma. The latter features a total protein titer of $\sim 70 \mathrm{mg} / \mathrm{mL}$, including an Ig titer of $9.7 \mathrm{mg} / \mathrm{mL}$ and an albumin titer of $\sim 60 \mathrm{mg} / \mathrm{mL}$ (note: small variations in protein titer are regularly observed among batches of pooled plasma depending on donors and initial processing) $\left[{ }^{47}\right]$. The plasma was diluted by either 10- or 20-fold with the selected binding buffer prior to injection on the column to overcome the innate buffering activity of plasma and achieve the ionic strength and $\mathrm{pH}$ needed to ensure effective capture of nonIg plasma proteins by the LigaGuard peptides. Further, the proposed dilution, by lowering the pIgG titer, reduces the likelihood of non-specific loss of product, while still maintaining a level non-Ig plasma proteins sufficient to ensure capture. The diluted plasma feedstock was loaded on the LigaGuard ${ }^{\mathrm{TM}}$ adsorbent at the residence time of $1 \mathrm{~min}$, and the resultant profiles of $Y_{p I g G}$ and $Q_{P P}$ vs.loading volume are collated in Figure $\mathbf{7 A}$ and Figure 7B ; the corresponding profiles of $C_{p I g G} / C_{p I g G}{ }^{*}$ and $C_{P P} / C_{P P} *$ are reported inFigure $\mathbf{7 C}$ and Figure 7D .

\section{Hosted file}

image7.emf available at https://authorea.com/users/425045/articles/529963-purification-ofpolyclonal-immunoglobulin-g-from-human-serum-using-ligaguardtm-and-ligatraptm-adsorbents

Figure 7. Profiles of $(\boldsymbol{A})$ pIgG flow-through yield $\left(Y_{p I g G}\right),(\boldsymbol{B})$ non-Ig plasma protein capture $\left(Q_{P P}\right),(\boldsymbol{C})$ ratio of pIg $G$ titer in the effluent vs. feedstock $\left(C_{p I g G} / C_{p I g G}{ }^{*}\right)$, and (D) ratio of non-Ig plasma protein titer in the effluent vs. feedstock $\left(C_{P P} / C_{P P}{ }^{*}\right)$ vs. loading volume obtained by injecting plasma diluted using 20 $\mathrm{mM}$ Bis-Tris HCl buffer at $\mathrm{pH} 6.0$ to a total protein titer of either $10 \mathrm{mg} / \mathrm{mL}$ (10-fold dilution, D10X) or $5.1 \mathrm{mg} / \mathrm{mL}$ (20-fold dilution, D20X) on first-generation LigaGuard ${ }^{T M}$ resin.

Most notably, the amount of pIgG captured by the resin $\left(Q_{p I g G}\right)$ was not affected by the dilution factor and plateaued at $\sim 2.5 \mathrm{mg}$ per $\mathrm{mL}$ of resin; conversely, the value $Q_{P P}$ at the cut-off loading volume doubled from 
$25 \mathrm{mg} / \mathrm{mL}$ to $50 \mathrm{mg} / \mathrm{mL}$ by decreasing dilution of the feedstock from 20-fold to 10-fold. This translated in a global $Y_{p I g G}$ at the load cut-off of $\sim 76.4 \%$ and a 1.7 -fold reduction of non-Ig plasma proteins from 10-fold diluted plasma, corresponding to a 0.59 -fold product enrichment in the effluent (Table 2 ). The improvement in the cut-off value of product yield obtained from loading the LigaGuard ${ }^{\mathrm{TM}}$ adsorbent with plasma in lieu of pure pIgG solution ( $Y_{p I g G} \sim 70 \%$ ) results from the presence of non-Ig plasma proteins outcompeting pIgG for binding the peptide ligands. Furthermore, the adsorbed pIgG was stripped from the column by chasing the loading with $2 \mathrm{CVs}$ binding buffer, which further increased $Y_{p I g G}$ up to $78.8 \%$ without compromising the global purity of the effluent. As shown by the electrophoretic analysis of the combined effluents in Figure 8 , product purity decreased from $46 \%$ to only $44 \%$ by adding a buffer chasing after loading the 10-fold diluted plasma, and the corresponding pIgG enrichment factor decreased slightly from 0.76 to 0.63 (Table 2 ).

Table 2. Values of $Y_{p I g G}$, reduction of non-Ig plasma proteins, and $p I g G$ enrichment factor in the effluent compared to feedstock obtained by loading $5 \mathrm{~mL}(10 \mathrm{CVs})$ of diluted plasma onto LigaGuard ${ }^{T M}$ adsorbent at 1 min residence time.

\begin{tabular}{|c|c|c|c|c|c|c|}
\hline $\begin{array}{l}\text { Diluted } \\
\text { plasma } \\
\text { feedstock } \\
\end{array}$ & $\mathrm{Y}_{\mathrm{pIgG}}$ & $\mathrm{Y}_{\mathrm{pIgG}}$ & $\begin{array}{l}\text { Reduction of } \\
\text { non-Ig } \\
\text { plasma } \\
\text { proteins }\end{array}$ & $\begin{array}{l}\text { Reduction of } \\
\text { non-Ig } \\
\text { plasma } \\
\text { proteins } \\
\end{array}$ & $\begin{array}{l}\text { pIgG } \\
\text { enrichment } \\
\text { factor }\end{array}$ & $\begin{array}{l}\text { pIgG } \\
\text { enrichment } \\
\text { factor }\end{array}$ \\
\hline & $\begin{array}{l}\text { Loading } \\
\text { only }\end{array}$ & $\begin{array}{l}\text { Loading }+ \\
\text { chasing }\end{array}$ & $\begin{array}{l}\text { Loading } \\
\text { only }\end{array}$ & $\begin{array}{l}\text { Loading }+ \\
\text { chasing }\end{array}$ & $\begin{array}{l}\text { Loading } \\
\text { only }\end{array}$ & $\begin{array}{l}\text { Loading }+ \\
\text { chasing }\end{array}$ \\
\hline 10-fold & $77 \%$ & $80 \%$ & $4.7^{\circ}$ & 4.9 & 1.3 & 1.0 \\
\hline 20-fold & $58 \%$ & $63 \%$ & 5.9 & 5.0 & 1.0 & 1.2 \\
\hline
\end{tabular}

\section{Hosted file}

image8.emf available at https://authorea.com/users/425045/articles/529963-purification-ofpolyclonal-immunoglobulin-g-from-human-serum-using-ligaguardtm-and-ligatraptm-adsorbents

Figure 8. SDS-PAGE analysis (reducing conditions, Coomassie staining) of the chromatographic fractions obtained by purifying pIgG from diluted cryo-rich plasma using LigaGuard ${ }^{T M}$ resin and $20 \mathrm{mM}$ Bis-Tris $\mathrm{HCl}$ buffer at pH 6.0 as binding buffer. Labels: Feed D10X, 10-fold diluted plasma; FT D10X 2 CV, flow-through fraction obtained by loading $1 \mathrm{~mL}$ of 10-fold diluted plasma; FT D10X $6 \mathrm{CV}$, flow-through fraction obtained by loading $3 \mathrm{~mL}$ of 10-fold diluted plasma; FT D10X $10 \mathrm{CV}$, flow-through fraction obtained by loading 5 mL of 10-fold diluted plasma (i.e., cut-off value of loading volume); FT D10X Chased, flow-through fraction obtained by chasing the loading of 10-fold diluted plasma with the corresponding binding buffer; FT D20X 2 $C V$, flow-through fraction obtained by loading $1 \mathrm{~mL}$ of 20-fold diluted plasma; FT D20X 6 CV, flow-through fraction obtained by loading $3 \mathrm{~mL}$ of 20-fold diluted plasma; FT D20X $10 \mathrm{CV}$, flow-through fraction obtained by loading $5 \mathrm{~mL}$ of 20-fold diluted plasma (i.e., cut-off value of loading volume); FT D20X Chased, flowthrough fraction obtained by chasing the loading of 20-fold diluted plasma with the corresponding binding buffer.

With the aim of increasing both $Y_{p I g G}$ and pIgG enrichment factor in the effluent, we modified the LigaGuard resin by improving and expanding its multi-modal binding character: specifically, the anion exchange component was strengthened by quaternizing the amine groups displayed on the cationic residues (i.e. , lysine, arginine, and histidine); further binding modalities were introduced by integrating polar and thiophilic moieties. We anticipated that the combination of amine quaternization and $\mathrm{pH} 6.0$ would increase the capture of non-Ig plasma proteins, which are for the most part anionic, while further reducing the capture of pIgG.

To evaluate this second-generation LigaGuard adsorbent, we repeated the flow-through studies with pure IgG and Ig-depleted plasma, while maintaining $20 \mathrm{mM}$ Bis-Tris $\mathrm{HCl}$ buffer at $\mathrm{pH} 6.0$ as the mobile phase and 1 minute residence time. The resultant profiles of $Y_{p I g G}$ and $Q_{P P}$ vs. loading volume are collated in 
Figure 9 , while the corresponding values of $C_{p I g G} / C_{p I g G} *$ and $Q_{p I g G}$, and $C_{P P} / C_{P P}{ }^{*}$ and $Q_{P P}$ are reported in Figures S5A andS5B, respectively.

\section{Hosted file}

image9.emf available at https://authorea.com/users/425045/articles/529963-purification-ofpolyclonal-immunoglobulin-g-from-human-serum-using-ligaguardtm-and-ligatraptm-adsorbents

Figure 9. Profiles of (A) pIgG flow-through yield ( $\left.Y_{p I g G}\right)$ and (B) non-Ig plasma protein capture ( $\left.Q_{P P}\right)$ vs. loading volume obtained by respectively injecting a solution of $\mathrm{pIgG}$ at $3.0 \mathrm{mg} / \mathrm{mL}$ and Ig-depleted plasma at $5.6 \mathrm{mg} / \mathrm{mL}$ in $20 \mathrm{mM}$ Bis-Tris $\mathrm{HCl}$ buffer at $\mathrm{pH} 6.0$ on second-generation LigaGuard ${ }^{T M}$ resin; (C) pIgG flow-through yield $\left(Y_{p I g G}\right)$ and $(\boldsymbol{D})$ purity $\left(P_{p I g G}\right)$ vs. loading volume, and $(\boldsymbol{E}) Q_{P P}$ vs. loading volume obtained by injecting cryo-rich plasma diluted using $20 \mathrm{mM}$ Bis-Tris HCl buffer at $\mathrm{pH} 6.0$ to a total protein titer of either $15 \mathrm{mg} / \mathrm{mL}$ (5-fold dilution, D5X), $7.0 \mathrm{mg} / \mathrm{mL}$ (10-fold dilution, D10X), or $3.9 \mathrm{mg} / \mathrm{mL}$ (20fold dilution, D20X) on second-generation LigaGuard ${ }^{T M}$ resin, $(\boldsymbol{F})$ pIgG flow-through yield $\left(Y_{p I g G}\right)$ and $(G)$ purity $\left(P_{p I g G}\right)$ vs. loading volume by injecting cryo-poor plasma diluted using $20 \mathrm{mM}$ Bis-Tris $\mathrm{HCl}$ buffer at $\mathrm{pH} 6.0$ to a total protein titer of $6.4 \mathrm{mg} / \mathrm{mL}$ (10-fold dilution, D10X).

The second-generation LigaGuard adsorbent provided a remarkable improvement in both product yield and capture of non-Ig plasma proteins. Notably, the $Q_{P P}$ at the cut-off value of loading $(10 \mathrm{CVs})$ grew from 24.1 $\mathrm{mg}$ per $\mathrm{mL}$ of the original LigaGuard resin to $37.6 \mathrm{mg} / \mathrm{mL}$ of second-generation LigaGuard resin; conversely, the $Q_{p I g G}$ at saturation remained unaltered at $3.8 \mathrm{mg} / \mathrm{mL}$, translating in a $Y_{p I g G}$ of $87.4 \%$ at the cut-off loading.

Following on these results, we proceeded with the flow-through purification of pIgG from cryo-rich plasma using the second-generation LigaGuard adsorbent. The plasma was diluted by either 5-, 10-, or 20-fold with $20 \mathrm{mM}$ Bis-Tris $\mathrm{HCl}$ buffer at $\mathrm{pH} 6.0$ and loaded on the LigaGuard ${ }^{\mathrm{TM}}$ adsorbent at the residence time of $1 \mathrm{~min}$. The resulting profiles of $Y_{p I g G}$ and $Q_{P P}$ vs. loading volume are reported inFigure 9C and Figure $\mathbf{9 E}$; the corresponding profiles of $C_{p I g G} / C_{p I g G}$ * are reported inFigures S6 . The loading of 20 -fold diluted plasma, where the titer of $\mathrm{pIgG}(0.6 \mathrm{mg} / \mathrm{mL})$ and non-Ig plasma proteins $(3.9 \mathrm{mg} / \mathrm{mL})$ are relatively low, resulted in efficient flow-through purification: the adsorbent became progressively saturated with plasma proteins throughout feedstock loading, while allowing pIgG to flow-through unbound. Accordingly, by the cut-off loading volume $(10 \mathrm{CVs})$, the cumulative pIgG purity in the effluent reached $98.1 \%$, as shown by the electrophoretic analysis in Figure 10A . The global yield, on the other hand, reached $25.4 \%$ only. This was imputed to the protein concentration in the feedstock being inadequate to match the higher binding capacity of the second-generation LigaGuard adsorbent: specifically, the titer of non-Ig plasma proteins was insufficient to prevent undesired capture of IgG or displace the bound pIgG molecules via the weak partitioning mechanism described in prior work [26, 27 ]. We therefore adjusted loading conditions by reducing the dilution of the feedstock to 10 -fold and 5-fold, which increased the titer of pIgG to 1.0 and $2.0 \mathrm{mg} / \mathrm{mL}$, and non-Ig plasma proteins to $\sim 7.2$ and $14.5 \mathrm{mg} / \mathrm{mL}$, respectively.

The loading of 10-fold diluted plasma resulted in a significant increase in pIgG yield with high purity; specifically, at the loading volume of $4.0 \mathrm{~mL}(8 \mathrm{CVs}), Y_{p I g G}$ and $Q_{P P}$ respectively reached $\sim 71 \%$ and $27 \mathrm{mg}$ per $\mathrm{mL}$ resin, corresponding to a cumulative product purity of $\sim 80 \%$; beyond this point, however, a significant amount of non-Ig proteins flow through the column, lowering product purity to $62 \%$ at the loading volume of $5.5 \mathrm{~mL}$. This is mirrored by the electrophoretic analysis of the effluent in Figure 10B , which shows that product purity is very high in the initial flow-through fractions ( $>85 \%$ up to $5 \mathrm{CVs}$ ), decreases slightly to $81 \%$ during the injection of the CVs 6 and 7, during which albumin bands appear, and finally drops to $72 \%$ (CVs 8 and 9), when more plasma proteins break through. Finally, the loading of 5-fold diluted plasma showed a significant loss of product yield and purity. Upon loading $5 \mathrm{CVs}$, in fact, non-Ig plasma proteins began breaking through $\left(C_{P P} / C_{P P} * \sim 5 \%\right)$ while the $Y_{p I g G}$ was still relatively low ( $\left.61 \%\right)$; yield increased appreciably through the subsequent loading phase, although product purity dropped significantly, reaching $76 \%$ at 10 CVs. The rather early breakthrough of non-Ig plasma proteins, visible in Figure $\mathbf{9 E}$, indicate the rapid saturation of the binding sites due to the high protein concentration. Collectively, these results indicate 
that the 10-fold dilution ratio is ideal for stripping non-Ig plasma proteins using the LigaGuard adsorbent prior to, or in lieu of, affinity-based capture to improve the performance of subsequent chromatographic steps and maximize product yield and purity.

The optimized loading conditions (10-fold dilution; $20 \mathrm{mM}$ Bis-Tris $\mathrm{HCl}$ buffer, $\mathrm{pH}$ 6.0; RT: 1 min) were implemented to purify pIgG from cryo-poor plasma. The resulting profiles of product yield and purityvs. loading volume reported in Figure 9F andFigure 9G (the profiles of $C_{p I g G} / C_{p I g G}$ * are inFigures S6 ) indicate a purification performance similar to that obtained with 20 -fold and 10-fold diluted cryo-rich plasma. At the loading volume of $8 \mathrm{CVs}$, for example, $Y_{p I g G} \sim 50 \%$ and $P_{p I g G}>93 \%\left(Q_{P P}>25.4 \mathrm{mg}\right.$ per $\mathrm{mL}$ of resin) are obtained. Interestingly, the $Y_{p I g G}$ profile features two slopes, namely $\sim 7 \% / \mathrm{CV}$ and $\sim 14 \% / \mathrm{CV}$, respectively before and after the loading volume of $7 \mathrm{CVs}$; this value also demarcates between the collection of high-purity effluent and the breakthrough of non-Ig plasma proteins, which lower the cumulative $P_{p I g G}$ from $99 \%$ to $82 \%$ at $10 \mathrm{CVs}$ (Figure 10D ). The profile of $Q_{P P}$, in fact, shows an inflection above $10 \mathrm{CVs}$, indicating the saturation of the LigaGuard adsorbent at $30 \mathrm{mg} / \mathrm{mL}$, coherently with prior measurements.

\section{Hosted file}

image10.emf available at https://authorea.com/users/425045/articles/529963-purification-ofpolyclonal-immunoglobulin-g-from-human-serum-using-ligaguardtm-and-ligatraptm-adsorbents

Figure 10. SDS-PAGE analysis (native conditions, Coomassie staining) of the chromatographic fractions obtained by purifying pIgG from cryo-rich plasma diluted using $20 \mathrm{mM}$ Bis-Tris $\mathrm{HCl}$ buffer at $\mathrm{pH} 6.0$ to a total protein titer of (A) $15 \mathrm{mg} / \mathrm{mL}$ (5-fold dilution, D5X), (B) $7.0 \mathrm{mg} / \mathrm{mL}$ (10-fold dilution, D10X), (C) $3.9 \mathrm{mg} / \mathrm{mL}$ (20-fold dilution, D20X), or (D)cryo-poor plasma diluted using $20 \mathrm{mM}$ Bis-Tris HCl buffer at pH 6.0 to a total protein titer of $6.04 \mathrm{mg} / \mathrm{mL}$ (10-fold dilution, D10X). Labels: MW, molecular weight latter; hIgG, human polyclonal IgG standard; F, diluted plasma feedstock; and FTi, i-th flow-through fraction.

\subsection{Purification of pIgG from cryo-rich plasma using a two-step process: Guard-Capture vs. Capture-Polish}

In prior work, we have demonstrated the use of LigaGuard ${ }^{\mathrm{TM}}$ resin as a scrubber of process-related impurities prior to the Protein A-based affinity capture step in a process of antibody purification from $\mathrm{CHO}$ cell culture fluids $\left[{ }^{26,27}\right]$. In analogy to that study, we attempted the purification of pIgG from plasma using a twocolumn process comprising a LigaGuard adsorbent that captures the non-Ig plasma proteins in flow-through followed by a LigaTrap ${ }^{\mathrm{TM}}$ adsorbent that operates in bind-and-elute mode to isolate and concentrate pIgG. The loading of diluted cryo-rich plasma was "chased" with 20 CVs of buffer C, and the pooled effluent (pIgG titer $0.2 \mathrm{mg} / \mathrm{mL}$ ) was adjusted to $\mathrm{pH} 7.4$ and loaded onto LigaTrap ${ }^{\mathrm{TM}}$ adsorbent. The "guard-capture" process conditions detailing loading, buffer composition, and residence time, along with the resulting values of $Y_{p I g G}$ and $P_{p I g G}$ in the fractions across the two-column process are listed in Figure $11 \mathbf{A}$, while the electrophoretic analysis is shown in Figure 11B. Notably, the depletion of non-Ig plasma protein by the LigaGuard adsorbent enabled a remarkable increase in the purity of $\mathrm{pIgG}$ eluted from the LigaTrap ${ }^{\mathrm{TM}}$ adsorbent $\left(P_{p I g G} \sim 99.9 \%\right)$. Most importantly, the capture of albumin, the major contaminant in the affinity capture step, greatly facilitated the clearance of the residual impurities by LigaTrap ${ }^{\mathrm{TM}}$ adsorbent, thus improving its effective binding capacity and selectivity. This process design, however, suffers from limited throughput. The high concentration of non- $\mathrm{Ig}$ plasma protein in the feed $(6.0 \mathrm{mg} / \mathrm{mL})$ and the binding capacity of the LigaGuard adsorbent (32 $\mathrm{mg}$ per $\mathrm{mL}$ of resin), in fact, pose a limit to the volume of feedstock that can be fed into the two-column process.

\section{Hosted file}

image11.emf available at https://authorea.com/users/425045/articles/529963-purification-ofpolyclonal-immunoglobulin-g-from-human-serum-using-ligaguardtm-and-ligatraptm-adsorbents

Figure 11.(A) Two-column process comprising the second-generation LigaGuard adsorbent operated in flowthrough mode followed by a LigaTrap ${ }^{T M}$ adsorbent operated in bind-and-elute mode, and corresponding process (i.e., loading, composition of the buffers, and residence time) and performance $\left(Y_{p I g G}\right.$ and $\left.P_{p I g G}\right)$ parameters; 
(B) SDS-PAGE analysis (reducing conditions, Coomassie staining) of the chromatographic fractions obtained by purifying pIgG from cryo-rich plasma diluted 10-fold using $20 \mathrm{mM}$ Bis-Tris $\mathrm{HCl}$ buffer at $\mathrm{pH} 6.0$ via the two-column process; labels: $M W$, molecular weight latter; hIgG, human polyclonal IgG standard; F, diluted plasma feedstock; FT-LG, flow-through fraction from the LigaGuard adsorbent; FT-LT, flow-through fraction from the LigaTrap adsorbent; and E-LT, elution fraction from the LigaTrap adsorbent.

The global yield of the two-column process is evidently limited by the first step ( $Y_{p I g G} \sim 49.9 \%$ ). In response to this challenge, we lowered the $\mathrm{pH}$ of feedstock from 6.0 to 5.5 to enhance the electrostatic repulsion between IgG and the second-generation LigaGuard adsorbent. All other process parameters were kept unaltered; the values of $Y_{p I g G}$ and $P_{p I g G}$ resulting from the analysis of the process fractions are shown in Figure S7 . This process adjustment raised the global yield to $63.8 \%$, without altering final product purity (99.7\%). For reference, the values of global pIgG yield obtained by processing Ig-rich Cohn fractions via ion exchange chromatography range between $40-70 \%[16,19,57,58]$.

In the attempt to further pIgG recovery and productivity, we proposed an alternative two-column process comprising an affinity-based capture step using LigaTrap ${ }^{\mathrm{TM}}$ adsorbent in bind-and-elute mode followed by a polishing step using the LigaGuard adsorbent operating in flow-through mode. The "capture-polish" process diagram, conditions, the resulting values of $Y_{p I g G}$ and $P_{p I g G}$, and electrophoretic analysis of the process fractions are reported in Figure 12 .

\section{Hosted file}

image12.emf available at https://authorea.com/users/425045/articles/529963-purification-ofpolyclonal-immunoglobulin-g-from-human-serum-using-ligaguardtm-and-ligatraptm-adsorbents

Figure 12. (A) Two-column process comprising the second-generation LigaTrap adsorbent operated in bind-and-elute mode followed by a LigaGuard ${ }^{T M}$ adsorbent operated in flow-through mode, and corresponding process (i.e., loading, composition of the buffers, and residence time) and performance $\left(Y_{p I g G}\right.$ and $\left.P_{p I g G}\right)$ parameters;(B) SDS-PAGE analysis (reducing conditions, Coomassie staining) of the chromatographic fractions obtained by purifying $\mathrm{pIg} G$ from cryo-rich plasma diluted 10-fold using $20 \mathrm{mM}$ Bis-Tris HCl buffer at $p H$ 6.0 via the two-column process; labels: $M W$, molecular weight latter; hIgG, human polyclonal IgG standard; HSA, human 6serum albumin; $F$, diluted plasma feedstock; FT+W-LT, flow-through and wash fraction from the LigaTrap adsorbent; FT-E, elution fraction from the LigaTrap adsorbent; FT-CIP, clean in place fraction from the LigaTrap adsorbent; and $F T n-L G$ ( $n=1,2$ and 3), flow-through fraction $n$ from the LigaGuard adsorbent.

Notably, preponing product capture improved substantially the global recovery $\left(Y_{p I g G} \sim 82.3 \%\right)$, while polishing still secured a high final product purity $\left(P_{p I g G} \sim 98.8 \%\right)$. Furthermore, the binding capacity of the LigaTrap adsorbent (10 mg per $\mathrm{mL}$ of resin) enabled a 1.7-fold increase in the volume of plasma processed by the "capture-polish" compared to that enabled by the "guard-capture" using identical column volumes. On the other hand, the "capture-polish" imposes an intermediate step of buffer adjustment of the elution stream from the LigaTrap adsorbent prior to loading into the LigaGuard adsorbent, which lengthens the process and makes it less streamlined; furthermore, conducting the polishing in flow-through mode reduces the product concentration, thereby imposing a subsequent ultrafiltration step.

The performance of the two alternative process designs is summarized inTable $\mathbf{3}$, which reports, together with product yield and purity, the corresponding values of enrichment of $\mathrm{pIgG}$ and the clearance of non-Ig plasma proteins in the product stream. The remarkable levels of purification achieved with the first process configuration demonstrate the potential of the proposed technology for the purification of plasma-derived therapeutics.

Table 3. Values of $Y_{p I g G}, P_{p I g G}$, reduction of non-Ig plasma proteins, and pIgG enrichment factor in the effluent compared to feedstock obtained by loading $1 \mathrm{~mL}$ cryo-rich plasma onto LigaGuard ${ }^{T M}$ and LigaTrap ${ }^{T M}$ adsorbents at different resin sequence and loading $\mathrm{pH}$. 


\begin{tabular}{|c|c|c|c|c|c|c|c|c|}
\hline $\begin{array}{l}\text { Two- } \\
\text { column } \\
\text { process }\end{array}$ & $\mathrm{Y}_{\mathrm{pIgG}}$ & $Y_{\mathrm{pIgG}}$ & $P_{\mathrm{pIgG}}$ & $\mathrm{P}_{\mathrm{pIgG}}$ & $\begin{array}{l}\text { Reduction } \\
\text { of non-Ig } \\
\text { plasma } \\
\text { proteins }\end{array}$ & $\begin{array}{l}\text { Reduction } \\
\text { of non-Ig } \\
\text { plasma } \\
\text { proteins }\end{array}$ & $\begin{array}{l}\text { pIgG en- } \\
\text { richment } \\
\text { factor }\end{array}$ & $\begin{array}{l}\text { pIgG e } \\
\text { richme } \\
\text { factor }\end{array}$ \\
\hline & $\begin{array}{l}\text { First } \\
\text { column }\end{array}$ & Global & $\begin{array}{l}\text { First } \\
\text { column }\end{array}$ & Global & $\begin{array}{l}\text { First } \\
\text { column }\end{array}$ & Global & $\begin{array}{l}\text { First } \\
\text { column }\end{array}$ & Global \\
\hline $\begin{array}{l}\mathrm{LG}+\mathrm{LT} \\
(\mathrm{pH} 5.5)\end{array}$ & $66.6 \%$ & $63.8 \%$ & $97.2 \%$ & $99.7 \%$ & 22 & 241 & 76 & 870 \\
\hline $\begin{array}{l}\mathrm{LG}+\mathrm{LT} \\
(\mathrm{pH} 6.0)\end{array}$ & $\sim 50 \%$ & $\sim 50 \%$ & $99.8 \%$ & $>99.9 \%$ & 37 & 366 & 134 & 1362 \\
\hline $\begin{array}{l}\mathrm{LT}+\mathrm{LG} \\
(\mathrm{pH} 6.0)\end{array}$ & $96.5 \%$ & $82.3 \%$ & $92.4 \%$ & $98.8 \%$ & 15 & 59 & 56 & 230 \\
\hline
\end{tabular}

\section{Conclusions}

The biomanufacturing of IVIG via isolation of $\mathrm{pIgG}$ from pooled plasma has been performed for over half a century via precipitation-based fractionation with minimal alterations since its initial design by Edwin Cohn and Lawrence Oncley in the mid 40s. While greatly indebted to the Cohn-Oncley process, the community of scientists and engineers operating in the space of blood-derived proteins have defined the need to turn towards more modern forms of biomanufacturing. In this context, protein chromatography using affinity adsorbents functionalized with synthetic ligands has gained momentum owing to a series of recent studies demonstrating its potential for IVIG isolation from crude plasma. Our group has invested significantly in this field by developing peptide- and peptoid-based ligands for pIgG purification from animal - human and other mammals - sources.

The two-step chromatographic process for pIgG purification from plasma proposed in this study demonstrates significant advantages compared to Cohn-derived processes in terms of process design, throughput, and product yield and quality. Current IVIG manufacturing, which relies on plasma fractionation via cold ethanol precipitation followed by ion-exchange purification, is in fact a disconnected process that suffers from the large footprint and extended times of precipitation processes as well as the low recovery and product dilution typical of ion-exchange chromatography. Conversely, the proposed two-step process is fully integrated, and provides product yield and purity comparable - or superior - to the current standard; furthermore, by operating $50 \%$ in flow-through mode, it provides a route towards process intensification by enabling smaller footprint and continuous operation under reduced residence time. Finally, when arranged in the "capturepolish" sequence it enables high productivity, while if arranged in the "guard-capture" sequence it provides for high product concentration.

The design conditions and the results presented in this study are by no means definitive. Further adjusting the design of both adsorbents and process is much needed. Specifically, we envision improving the binding capacity and selectivity of the LigaGuard adsorbent by further adjusting ligand composition and surface density as well as pore and particle size; advancing the process by exploring in more detail the effects of composition, concentration, and $\mathrm{pH}$ of the buffer as well as loading rates and residence times; and introducing intermediate steps - e.g. , a tangential flow filtration - for continuous adjustment of buffer composition and protein concentration between the LigaGuard and LigaTrap adsorbents. Nonetheless, the technology proposed in this study is the core of a new technology that shows tremendous potential for a leap forward in the plasma fractionation technology for large-scale IVIG manufacturing.

Acknowledgements. The authors wish to acknowledge CSL Behring for funding this work; the authors specifically acknowledge Amy Carruthers, David Boerema, Nathan Brinkman, and Laura Keigher at CSL Behring for discussing our results and providing directions in completing this work.

Conflict of interest. The authors Michael Crapanzano (CEO, Ligatrap) and Jae Sly (CBO, LigaTrap) declare conflict of interest. 


\section{References}

[1] Barahona Afonso, A. F., and João, C. M. P. (2016) The Production Processes and Biological Effects of Intravenous Immunoglobulin, Biomolecules $6,15-15$.

[2] Durandy, A., Kaveri, S. V., Kuijpers, T. W., Basta, M., Miescher, S., Ravetch, J. V., and Rieben, R. (2009) Intravenous immunoglobulins - understanding properties and mechanisms, Clinical \& Experimental Immunology $158,2-13$.

[3] Grayzel, A., Solomon, A., Aranow, C., and Diamond, B. (1991) Antibodies elicited by pneumococcal antigens bear an anti-DNA-associated idiotype, The Journal of Clinical Investigation 87, 842-846.

[4] Eibl, M. M. (2008) History of immunoglobulin replacement,Immunology and allergy clinics of North America 28 , 737-764, viii.

[5] Nimmerjahn, F., and Ravetch, J. V. (2008) Anti-inflammatory actions of intravenous immunoglobulin, Annual review of immunology 26, 513-533.

[6] Conley, M. E., Dobbs, A. K., Farmer, D. M., Kilic, S., Paris, K., Grigoriadou, S., Coustan-Smith, E., Howard, V., and Campana, D. (2009) Primary B cell immunodeficiencies: comparisons and contrasts, Annual review of immunology 27, 199-227.

[7] ElBakri, A., Nelson, P. N., and Abu Odeh, R. O. (2010) The state of antibody therapy, Human Immunology $71,1243-1250$.

[8] Menegatti, S., Naik, A. D., Gurgel, P. V., and Carbonell, R. G. (2012) Purification of polyclonal antibodies from Cohn fraction II + III, skim milk, and whey by affinity chromatography using a hexamer peptide ligand, Journal of Separation Science 35 , 3139-3148.

[9] Hung, I. F. N., To, K. K. W., Lee, C. K., Lee, K. L., Yan, W. W., Chan, K., Chan, W. M., Ngai, C. W., Law, K. I., Chow, F. L., Liu, R., Lai, K. Y., Lau, C. C. Y., Liu, S. H., Chan, K. H., Lin, C. K., and Yuen, K. Y. (2013) Hyperimmune IV immunoglobulin treatment: a multicenter double-blind randomized controlled trial for patients with severe 2009 influenza A(H1N1) infection, Chest 144 , 464-473.

[10] Luke, T. C., Casadevall, A., Watowich, S. J., Hoffman, S. L., Beigel, J. H., and Burgess, T. H. (2010) Hark back: passive immunotherapy for influenza and other serious infections, Critical care medicine 38 , e66-73.

[11] Klein, S. L., Pekosz, A., Park, H. S., Ursin, R. L., Shapiro, J. R., Benner, S. E., Littlefield, K., Kumar, S., Naik, H. M., Betenbaugh, M. J., Shrestha, R., Wu, A. A., Hughes, R. M., Burgess, I., Caturegli, P., Laeyendecker, O., Quinn, T. C., Sullivan, D., Shoham, S., Redd, A. D., Bloch, E. M., Casadevall, A., and Tobian, A. A. (2020) Sex, age, and hospitalization drive antibody responses in a COVID-19 convalescent plasma donor population, J Clin Invest 130 , 6141-6150.

[12] Boonyaratanakornkit, J., Morishima, C., Selke, S., Zamora, D., McGuffin, S., Shapiro, A. E., Campbell, V. L., McClurkan, C. L., Jing, L., Gross, R., Liang, J., Postnikova, E., Mazur, S., Lukin, V. V., Chaudhary, A., Das, M. K., Fink, S. L., Bryan, A., Greninger, A. L., Jerome, K. R., Holbrook, M. R., Gernsheimer, T. B., Wener, M. H., Wald, A., and Koelle, D. M. (2021) Clinical, laboratory, and temporal predictors of neutralizing antibodies against SARS-CoV-2 among COVID-19 convalescent plasma donor candidates, $J$ Clin Invest 131.

[13] Bonam, S. R., Kaveri, S. V., Sakuntabhai, A., Gilardin, L., and Bayry, J. (2020) Adjunct Immunotherapies for the Management of Severely Ill COVID-19 Patients, Cell reports. Medicine 1, 100016.

[14] Menegatti, S., Bobay, B. G., Ward, K. L., Islam, T., Kish, W. S., Naik, A. D., and Carbonell, R. G. (2016) Design of protease-resistant peptide ligands for the purification of antibodies from human plasma, Journal of Chromatography A 1445, 93-104. 
[15] Cohn, E. J., Strong, L. E., Hughes, W. L., Mulford, D. J., Ashworth, J. N., Melin, M., and Taylor, H. L. (1946) Preparation and Properties of Serum and Plasma Proteins. IV. A System for the Separation into Fractions of the Protein and Lipoprotein Components of Biological Tissues and Fluids1a,b,c,d, Journal of the American Chemical Society 68, 459-475.

[16] Oncley, J. L., Melin, M., Richert, D. A., Cameron, J. W., and Gross, P. M. (1949) The Separation of the Antibodies, Isoagglutinins, Prothrombin, Plasminogen and $\beta 1$-Lipoprotein into Subfractions of Human Plasma, Journal of the American Chemical Society 71, 541-550.

[17] Kistler, P., and Nitschmann, H. (1962) Large scale production of human plasma fractions. Eight years experience with the alcohol fractionation procedure of Nitschmann, Kistler and Lergier, Vox sanguinis 7 , 414-424.

[18] Radosevich, M., and Burnouf, T. (2010) Intravenous immunoglobulin G: trends in production methods, quality control and quality assurance, Vox sanguinis 98 , 12-28.

[19] Buchacher, A., and Iberer, G. (2006) Purification of intravenous immunoglobulin G from human plasma - aspects of yield and virus safety, Biotechnology Journal 1, 148-163.

[20] Martin, T. D. (2006) IGIV: contents, properties, and methods of industrial production-evolving closer to a more physiologic product,International immunopharmacology 6 , 517-522.

[21] Follman, D. K., and Fahrner, R. L. (2004) Factorial screening of antibody purification processes using three chromatography steps without protein A, Journal of Chromatography A 1024, 79-85.

[22] Hober, S., Nord, K., and Linhult, M. (2007) Protein A chromatography for antibody purification, Journal of Chromatography B 848, 40-47.

[23] Burnouf, T. (2018) An overview of plasma fractionation, Annals of Blood .

[24] Romberg, V., Hoefferer, L., and El Menyawi, I. (2015) Effects of the manufacturing process on the anti-A isoagglutinin titers in intravenous immunoglobulin products, Transfusion 55 Suppl 2, S105-109.

[25] Lavoie, R. A., di Fazio, A., Blackburn, R. K., Goshe, M. B., Carbonell, R. G., and Menegatti, S. (2019) Targeted Capture of Chinese Hamster Ovary Host Cell Proteins: Peptide Ligand Discovery, Int J Mol Sci 20 .

[26] Lavoie, R. A., di Fazio, A., Williams, T. I., Carbonell, R., and Menegatti, S. (2020) Targeted capture of Chinese hamster ovary host cell proteins: Peptide ligand binding by proteomic analysis,Biotechnol Bioeng $117,438-452$.

[27] Lavoie, R. A., Chu, W., Lavoie, J. H., Hetzler, Z., Williams, T. I., Carbonell, R., and Menegatti, S. (2021) Removal of host cell proteins from cell culture fluids by weak partitioning chromatography using peptide-based adsorbents, Separation and Purification Technology 257 , 117890.

[28] Reese, H. R., Xiao, X., Shanahan, C. C., Chu, W., Van Den Driessche, G. A., Fourches, D., Carbonell, R. G., Hall, C. K., and Menegatti, S. (2020) Novel peptide ligands for antibody purification provide superior clearance of host cell protein impurities, Journal of chromatography. A 1625 , 461237.

[29] Reese, H., Bordelon, T., Shanahan, C., Crapanzano, M., Sly, J., and Menegatti, S. (2020) Novel peptoidbased adsorbents for purifying IgM and IgG from polyclonal and recombinant sources, Journal of chromatography. B, Analytical technologies in the biomedical and life sciences 1137, 121909.

[30] Bordelon, T., Bobay, B., Murphy, A., Reese, H., Shanahan, C., Odeh, F., Broussard, A., Kormos, C., and Menegatti, S. (2019) Translating antibody-binding peptides into peptoid ligands with improved affinity and stability, Journal of chromatography. A 1602 , 284-299.

[31] Reese, H., Bordelon, T., Odeh, F., Broussard, A., Kormos, C., Murphy, A., Shanahan, C., and Menegatti, S. (2020) Purification of animal immunoglobulin G ( $\operatorname{IgG}$ ) using peptoid affinity ligands, Biotechnol Prog 36 
, e2994.

[32] Bordelon, T., Bobay, B., Murphy, A., Reese, H., Shanahan, C., Odeh, F., Broussard, A., Kormos, C., and Menegatti, S. (2019) Translating antibody-binding peptides into peptoid ligands with improved affinity and stability, Journal of Chromatography A 1602, 284-299.

[33] Reese, H., Bordelon, T., Odeh, F., Broussard, A., Kormos, C., Murphy, A., Shanahan, C., and Menegatti, S. Purification of animal immunoglobulin G (IgG) using peptoid affinity ligands, Biotechnology Progress $n / a$ , e2994.

[34] Lavoie, R. A., di Fazio, A., Blackburn, R. K., Goshe, M. B., Carbonell, R. G., and Menegatti, S. (2019) Targeted Capture of Chinese Hamster Ovary Host Cell Proteins: Peptide Ligand Discovery,International Journal of Molecular Sciences 20 , 1729.

[35] Liu, Z., Gurgel, P. V., and Carbonell, R. G. (2013) Affinity chromatographic purification of human immunoglobulin a from chinese hamster ovary cell culture supernatant, Biotechnology Progress29 , 91-98.

[36] Kish, W. S., Naik, A. D., Menegatti, S., and Carbonell, R. G. (2013) Peptide-Based Affinity Adsorbents with High Binding Capacity for the Purification of Monoclonal Antibodies, Industrial $\&$ Engineering Chemistry Research 52, 8800-8811.

[37] Wang, R.-Z., Lin, D.-Q., Chu, W.-N., Zhang, Q.-L., and Yao, S.-J. (2016) New tetrapeptide ligands designed for antibody purification with biomimetic chromatography: Molecular simulation and experimental validation, Biochemical Engineering Journal 114 , 191-201.

[38] Reese, H., Bordelon, T., Shanahan, C., Crapanzano, M., Sly, J., and Menegatti, S. (2020) Novel peptoidbased adsorbents for purifying IgM and IgG from polyclonal and recombinant sources, Journal of Chromatography B $1137,121909$.

[39] Products: Chicken IgY, In LigaTrap TECHNOLOGIES, https://www.ligatrap.com/product/chickenigy/.

[40] Luo, Y. D., Zhang, Q. L., Yuan, X. M., Shi, W., Yao, S. J., and Lin, D. Q. (2017) Selectivity evaluation and separation of human immunoglobulin G, Fab and Fc fragments with mixed-mode resins, J. Chromatogr. B 1040, 105-111.

[41] Bumbaca, D., Boswell, C. A., Fielder, P. J., and Khawli, L. A. (2012) Physiochemical and biochemical factors influencing the pharmacokinetics of antibody therapeutics, AAPS J 14, 554-558.

[42] Jin, Y., Luo, G., Oka, T., and Manabe, T. (2002) Estimation of isoelectric points of human plasma proteins employing capillary isoelectric focusing and peptide isoelectric point markers,Electrophoresis 23 , 3385-3391.

[43] Tong, H. F., Lin, D. Q., Gao, D., Yuan, X. M., and Yao, S. J. (2013) Caprylate as the albuminselective modifier to improve IgG purification with hydrophobic charge-induction chromatography, Journal of Chromatography A 1285, 88-96.

[44] Lavoie, R. A., di Fazio, A., Carbonell, R. G., and Menegatti, S. (2019) Multiplexed Competitive Screening of One-Bead-One-Component Combinatorial Libraries Using a ClonePix 2 Colony Sorter,International journal of molecular sciences $20,5119$.

[45] Saberi-Bosari, S., Omary, M., Lavoie, A., Prodromou, R., Day, K., Menegatti, S., and San-Miguel, A. (2019) Affordable Microfluidic Bead-Sorting Platform for Automated Selection of Porous Particles Functionalized with Bioactive Compounds, Scientific Reports9 .

[46] Lavoie, R. A., Chu, W. N., Lavoie, J. H., Hetzler, Z., Williams, T. I., Carbonell, R., and Menegatti, S. (2021) Removal of host cell proteins from cell culture fluids by weak partitioning chromatography using peptide-based adsorbents, Separation and Purification Technology 257. 
[47] Gupta, A. (2019) Plasma Proteins, In Comprehensive Biochemistry for Dentistry: Textbook for Dental Students (Gupta, A., Ed.), pp 67-75, Springer Singapore, Singapore.

[48] Tait, A. S., Hogwood, C. E. M., Smales, C. M., and Bracewell, D. G. (2012) Host cell protein dynamics in the supernatant of a mAb producing CHO cell line, Biotechnol. Bioeng. 109, 971-982.

[49] Hogwood, C. E. M., Ahmad, S. S., Tarrant, R. D., Bracewell, D. G., and Smales, C. M. (2016) An ultra scale-down approach identifies host cell protein differences across a panel of $\mathrm{mAb}$ producing $\mathrm{CHO}$ cell line variants, Biotechnology Journal $11,415-424$.

[50] Schmitt, M. G., White, R. N., and Barnard, G. C. (2020) Development of a high cell density transient $\mathrm{CHO}$ platform yielding mAb titers greater than $2 \mathrm{~g} / \mathrm{L}$ in only 7 days, Biotechnology Progress36, e3047.

[51] Peptide Calculator, https://www.bachem.com/knowledge-center/peptide-calculator/, Bachem.

[52] Vlasova, I. M., and Saletsky, A. M. (2009) Study of the denaturation of human serum albumin by sodium dodecyl sulfate using the intrinsic fluorescence of albumin, Journal of Applied Spectroscopy 76 , 536-541.

[53] Purtell, J. N., Pesce, A. J., Clyne, D. H., Miller, W. C., Pollak, V. E., Bramlage, R., Snider, T., and Vitale, P. (1979) Isoelectric point of albumin: Effect on renal handling of albumin, Kidney International 16 , 366-376.

[54] Gaevskaia, V. A., and Azhitskiı̌, G. (1978) [Isoelectric fractions of healthy human serum albumin and their ability to bind bilirubin], Ukrainskii biokhimicheskii zhurnal (1978)50 , 735-738.

[55] Ejima, D., Tsumoto, K., Fukada, H., Yumioka, R., Nagase, K., Arakawa, T., and Philo, J. S. (2007) Effects of acid exposure on the conformation, stability, and aggregation of monoclonal antibodies, Proteins $66,954-962$.

[56] Wang, W., Singh, S., Zeng, D. L., King, K., and Nema, S. (2007) Antibody Structure, Instability, and Formulation, Journal of Pharmaceutical Sciences 96 , 1-26.

[57] Kistler, P., and Nitschmann, H. (1962) Large Scale Production of Human Plasma Fractions, Vox sanguinis 7 , 414-424.

[58] Laursen, I., Teisner, B. (1999) PROCESS FOR PRODUCING IMMUNOGLOBULINS FOR INTRAVENOUS ADMINISTRATION AND OTHER IMMUNOGLOBULIN PRODUCTS.

[59] Cohn, E. J., Oncley, J. L., Strong, L. E., Hughes, W. L., and Armstrong, S. H. (1944) Chemical, clinical, and immunological studies on the products of human plasma fractionation. I. The characterization of the protein fractions of human plasma, J. Clin. Invest.23 , 417-432.

[60] Sparrow, R. L., Greening, D. W., and Simpson, R. J. (2011) A protocol for the preparation of cryoprecipitate and cryodepleted plasma, Methods in molecular biology (Clifton, N.J.) 728 , 259-265.

[61] Liu, Z., Gurgel, P. V., and Carbonell, R. G. (2012) Purification of human immunoglobulins A, G and M from Cohn fraction II/III by small peptide affinity chromatography, Journal of Chromatography A 1262 , 169-179.

[62] Marucco, A., Fenoglio, I., Turci, F., Fubini, B., and Iop. (2013) Interaction of fibrinogen and albumin with titanium dioxide nanoparticles of different crystalline phases, In Nanosafe 2012: International Conferences on Safe Production and Use of Nanomaterials .

[63] Cryoprecipitate (Blood Component), Medscape, https://reference.medscape.com/drug/cryocryoprecipitate-999498\#10.

[64] Coagulation factor VIII, DRUGBANK, https://go.drugbank.com/polypeptides/P00451.

[65] Fulcher, C. A., Ruggeri, Z. M., and Zimmerman, T. S. (1983) Isoelectric Focusing of Human von Willebrand Factor in Urea-Agarose Gels, Blood 61 , 304-310. 
[66] Fibronectin, Signaling Gateway - UCSD Molecule, http://www.signalinggateway.org/molecule/query?afcsid=A000942. 